\title{
Biochar amendment and phosphorus fertilization altered forest soil microbial community and native soil organic matter molecular composition
}

\author{
Perry J. Mitchell, André J. Simpson, Ronald Soong, Jonathan S. \\ Schurman Sean C. Thomas, Myrna J. Simpson
}

\begin{abstract}
Version Post-print/accepted manuscript
Citation Mitchell, P.J., Simpson, A.J., Soong, R. et al. Biogeochemistry (2016)

(published version) 130: 227. https://doi.org/10.1007/s10533-016-0254-0

Publisher's statement This is a post-peer-review, pre-copyedit version of an article published in Biogeochemistry. The final authenticated version is available online at: https://doi.org/10.1007/s10533-016-0254-0.
\end{abstract}

How to cite TSpace items

Always cite the published version, so the author(s) will receive recognition through services that track citation counts, e.g. Scopus. If you need to cite the page number of the author manuscript from TSpace because you cannot access the published version, then cite the TSpace version in addition to the published version using the permanent URI (handle) found on the record page.

This article was made openly accessible by $U$ of $T$ Faculty.

Please tell us how this access benefits you. Your story matters. 
1 Biochar amendment and phosphorus fertilization altered forest soil microbial community and native soil organic matter molecular composition

4 Perry J. Mitchell ${ }^{\mathrm{a}, \mathrm{b}}$, André J. Simpson, ${ }^{\mathrm{a}, \mathrm{b}}$, Ronald Soong ${ }^{\mathrm{b}}$, Jonathan S. Schurman ${ }^{\mathrm{c}}$, Sean C. Thomas ${ }^{\mathrm{c}}$, $5 \quad$ Myrna J. Simpson ${ }^{\mathrm{a}, \mathrm{b} *}$

6 a Department of Chemistry, University of Toronto, 80 St. George Street, Toronto, ON, M5S 3H6, 7 Canada; ${ }^{b}$ Environmental NMR Centre and Department of Physical and Environmental Sciences, 8 University of Toronto Scarborough, 1265 Military Trail, Toronto, ON, M1C 1A4, Canada; ${ }^{\mathrm{c}}$ Faculty of 9 Forestry, University of Toronto, 33 Willcocks Street, Toronto, ON, M5S 3B3, Canada; * Corresponding 10 author: Tel.: +1 (416) 287-7234, Fax: +1 (416) 287-7279, E-mail address: myrna.simpson@utoronto.ca 11 (M.J. Simpson).

Abstract

Fertilizer application to nutrient-deficient forest soils may alleviate soil nutrient limitations, but 15 long-term application may be cost-prohibitive and logistically challenging to apply to large areas. 16 Biochar has been proposed as a soil amendment to increase soil carbon storage and may emulate 17 fertilizer application by increasing soil nutrient availability. However, biochar may also stimulate 18 microbial activity, potentially accelerating native soil organic matter (OM) decomposition and altering 19 soil OM molecular composition. Here we compare changes in soil microbial activity and native OM 20 composition in a P-limited temperate hardwood forest in Ontario, Canada three years after the 21 amendment of biochar and $\mathrm{P}$ fertilizer using a factorial design experiment. Phospholipid fatty acid 22 analysis indicated that fungal activity was stimulated by biochar and biochar $+\mathrm{P}$ addition but not $\mathrm{P}$ 23 amendment alone, while bacterial activity increased with all treatments. Concentrations of solvent24 extractable acyclic and cyclic lipids, base-hydrolyzable cutin and suberin components, and lignin- 
derived phenols increased with biochar and biochar $+\mathrm{P}$ amendment and to a lesser extent with $\mathrm{P}$

fertilization. Biomarker ratios indicated soil OM compositional shifts toward greater proportions of cyclic vs. acyclic aliphatic lipids and lignin-derived phenol monomers vs. dimers with biochar and biochar $+\mathrm{P}$ amendment, but not with $\mathrm{P}$ fertilization. Solution-state nuclear magnetic resonance analysis of base-extractable soil OM showed increased proportions of aliphatic lipids and lignin and fewer carbohydrates with all treatments. The results suggest that biochar amendment may alleviate nutrient deficiencies in P-limited forest ecosystems. However, biochar altered the soil microbial community structure and shifted the native soil OM composition toward a greater proportion of recalcitrant OM, which may alter soil OM turnover and nutrient cycling rates with long-term biochar amendment.

\section{Keywords}

Soil fertility, biomarkers, nuclear magnetic resonance, phospholipid fatty acids, suberin, cutin, lignin

\section{Introduction}

Nutrient limitation in temperate forest soils is a major impediment to plant growth and soil fertility (Gress et al. 2007). Forest soil nutrient deficiencies may be addressed through the addition of $\mathrm{N}$ and P fertilizers or lime (Sullivan et al. 2014; Moore et al. 2015), but the application of these amendments may be problematic in the long-term. For example, fertilizers are costly and thus may have important implications for the sustainability and economics of forest management (Cole 1995; Hedwall et al. 2014). These amendments may also require repeated or frequent application (Brockley 2007; Hedwall et al. 2010; Bergh et al. 2014), and nutrient runoff can lead to a reduction in water quality in nearby watersheds (Fenn et al. 1998; Binkley et al. 1999). Furthermore, fertilizer and lime application have been linked to increased fluxes of soil greenhouse gases such as $\mathrm{CO}_{2}$ and $\mathrm{N}_{2} \mathrm{O}$ (Sitaula et al. 1995; 
49 from the pyrolysis of organic material (Lehmann and Joseph 2009), has been demonstrated to increase 50 soil water-holding and cation exchange capacities, buffer the $\mathrm{pH}$ of acidic soils, and sorb phytotoxic 51 compounds (Biederman and Harpole 2013). In addition, biochar can persist for centuries to millennia in 52 the environment, and the conversion of labile biomass $\mathrm{C}$ to biochar may increase soil $\mathrm{C}$ storage and 53 mitigate increasing atmospheric $\mathrm{CO}_{2}$ concentrations that contribute to global climate change (Lehmann 54 2007). Studies examining biochar application to soil have primarily focused on agricultural ecosystems 55 due to the economic and societal benefits associated with improved crop yields (Jeffery et al. 2011). In comparison, less research has focused on biochar addition to forests, especially in temperate ecosystems 57 (Gundale and DeLuca 2006; Santos et al. 2012; Singh et al. 2014; Noyce et al. 2015; Sackett et al. 2015). However, biochar application to forest soils may provide similar benefits as in agricultural systems. For example, biochar may increase soluble ion concentrations in nutrient-deficient forest soils (Thomas and Gale 2015; Zhu et al. 2015) through both the sorptive retention of cations and the addition 61 of feedstock-derived inorganic ash components (Lehmann et al. 2011). Previous studies have reported stimulated soil microbial activity (increased soil $\mathrm{CO}_{2}$ respiration)

63 following biochar amendment (Steinbeiss et al. 2009; Ameloot et al. 2013; Gomez et al. 2014), and shifts in the microbial community composition of biochar-amended soils have been observed using 65 phospholipid fatty acid (PLFA) biomarkers (Prayogo et al. 2014; Watzinger et al. 2014; Mitchell et al. 2015). In contrast to fertilizer addition which may stimulate microbial activity by directly alleviating nutrient deficiencies (Cleveland et al. 2002; Zhu et al. 2015), biochar likely enhances microbial activity as a result of several favourable changes to soil properties. For example, biochar may improve soil physical structure and aeration, increase soil nutrient concentrations and $\mathrm{pH}$, as well as provide macroporous environments that favour microbial colonization and offer microbes protection from 71 predators (Lehmann et al. 2011; McCormack et al. 2013; Gul et al. 2015). Since microbes are the 72 primary decomposers of organic matter (OM) in soil (Sheibani et al. 2013), biochar-induced changes in 
microbial activity and community composition may alter soil $\mathrm{C}$ turnover. For example, both positive and negative priming of soil $\mathrm{C}$ has been reported during biochar amendment, which may decrease or increase native soil C stocks, respectively (Cross and Sohi 2011; Keith et al. 2011; Luo et al. 2011; Zimmerman et al. 2011; Maestrini et al. 2014). However, it remains unclear how the overall composition of native soil OM is altered by biochar addition to soil, including changes in the proportions of specific types of OM components. For example, enhanced microbial activity may decrease the concentration of labile, easily-degradable OM components such as sugars, peptides and protein, resulting in an accumulation of more recalcitrant OM constituents such as long-chain aliphatic

lipids (von Lützow et al. 2006; Mitchell et al. 2016). Since soil OM plays a critical role in global biogeochemical cycles (Lal 2008), it is important to assess whether biochar alters the native soil OM composition to further evaluate the feasibility of applying biochar to nutrient-limited forest soils.

This study focuses on a three-year, field-scale amendment experiment conducted in a mixed hardwood temperate forest located in central Ontario, Canada, in the Great Lakes-St. Lawrence region. This area receives high levels of $\mathrm{N}$ deposition as a result of anthropogenic emissions in eastern North America (Environment Canada 2005; Vet and Ro 2008). Previous studies have reported evidence of essential plant nutrient deficiencies in soils of this region, primarily $\mathrm{P}$, while $\mathrm{K}, \mathrm{Ca}$ and $\mathrm{Mg}$ may be limiting secondarily (Gradowski and Thomas 2006; Casson et al. 2012). P fertilizer and lime application may be used to correct the altered soil nutrient ratios which result from elevated $\mathrm{N}$ inputs (Gradowski and Thomas 2006; Peng and Thomas 2010; Moore and Ouimet 2014; Moore et al. 2015; Sackett et al. 2015). Biochar amendment may also provide long-term supplementation of these limiting soil nutrients through the slow release and sorptive retention of ions (Mukherjee and Zimmerman 2013). Furthermore, if biochar is prepared on-site from forest biomass, it may be a more cost-effective amendment than fertilizer with the benefit of enhancing soil C sequestration (Thomas and Gale 2015). Previous studies at this forest reported that biochar addition (5 t/ha) increased soil $\mathrm{CO}_{2}$ respiration as well as the 
97 concentration of several limiting soil nutrients, including $\mathrm{PO}_{4}^{3-}, \mathrm{K}^{+}, \mathrm{Ca}^{2+}$ and $\mathrm{Mg}^{2+}$, whereas $\mathrm{P}$

98 fertilization $(200 \mathrm{~kg} / \mathrm{ha})$ decreased the abundance of mycorrhizal fungi in the mineral soil as a result of

99 alleviated nutrient deficiencies after only one year (Noyce et al. 2015; Sackett et al. 2015). To further

100 investigate potential changes in the soil microbial community composition and soil OM chemistry with

101 P fertilization and different biochar application rates over a longer time scale, the present study used a

102 factorial design setup to compare soil responses to biochar $(0,5,10$ and $20 \mathrm{t} / \mathrm{ha})$ and $\mathrm{P}(0$ or $200 \mathrm{~kg} / \mathrm{ha})$

103 amendments separately as well as to a combined biochar $+\mathrm{P}$ treatment three years post-amendment.

104 Shifts in the soil microbial community structure were examined using PLFAs (Frostegård and Bååth

105 1996), while changes in the native soil OM composition were assessed using soil OM biomarker and

106 solution-state nuclear magnetic resonance (NMR) spectroscopy techniques (Feng and Simpson 2011).

107 We hypothesize that biochar and P amendment in this forest soil will increase soil fertility by directly

108 providing available forms of $\mathrm{P}$ and other limiting plant nutrients, leading to increased bacterial and

109 fungal activity and enhanced mineralization (positive priming) of forest floor litter and native soil OM.

110 Our overall research objective is to examine biochar- vs. P-induced changes in microbial activity and

111 soil OM composition using the aforementioned molecular-level techniques to evaluate the potential 112 advantages and disadvantages of using biochar as a soil amendment in a nutrient-limited managed forest 113 ecosystem.

115 Materials and methods

116 Experimental design and sample collection

117 The biochar and P amendment study was conducted at the Haliburton Forest and Wild Life 118 Reserve Ltd. in central Ontario, Canada $\left(45.29^{\circ} \mathrm{N}, 78.64^{\circ} \mathrm{W}\right)$. This temperate hardwood forest contains 119 primarily deciduous trees and is dominated by sugar maple (Acer saccharum Marshall). The mean 120 annual temperature and precipitation at the site are $1075 \mathrm{~mm}$ and $5{ }^{\circ} \mathrm{C}$, respectively (Environment 
121 Canada 2015; Sackett et al. 2015). The soil at the study site is classified as a Brunisol under the

122 Canadian System of Soil Classification, an Inceptisol under the USDA Soil Taxonomy system and a

123 Cambisol under the FAO World Reference Base soil classification system (Soil Classification Working

124 Group 1998). The experiment was designed to test two factors: different biochar application rates (0, 5,

12510 and $20 \mathrm{t} / \mathrm{ha}$ ) and $\mathrm{P}$ amendment (unfertilized or fertilized with $\mathrm{Ca}\left(\mathrm{H}_{2} \mathrm{PO}_{4}\right)_{2}$ at a rate of $200 \mathrm{~kg} / \mathrm{ha}$ ). The

126 biochar application rates were selected based on previously published biochar amendment studies in

127 temperate ecosystems (Steinbeiss et al. 2009; Smith et al. 2010; Case et al. 2012; Nelissen et al. 2012;

128 Ameloot et al. 2013). The $\mathrm{P}$ application rate was based on previous research which assessed both

129 microbial and plant responses to soil $\mathrm{P}$ fertilization at the Haliburton Forest (Gradowski and Thomas

130 2008; Noyce et al. 2015; Sackett et al. 2015). Using a factorial design, a total of 8 treatments were tested

131 with five replicate plots per treatment, for a total of 40 experimental plots. The plots were $1 \times 1 \mathrm{~m}$ in

132 size and were delineated within a $60 \times 20 \mathrm{~m}$ area of the forest in September 2011 using a randomized

133 block design. Sugar maple sawdust (particle size range of 0.5-5 mm diameter) was pyrolyzed in several

134 batches on-site using a small-scale, $80 \mathrm{~L}$ capacity rotating kiln heated by a flame to maximum treatment

135 temperatures between $350-450{ }^{\circ} \mathrm{C}$, with an average maximum temperature of $400{ }^{\circ} \mathrm{C}$. The temperature

136 inside the pyrolyzer was measured by a high-temperature thermocouple inserted into the center of the

137 reaction chamber. During pyrolysis, the samples were held at the maximum temperature for

138 approximately $40 \mathrm{~min}$ to ensure thorough pyrolysis and all resulting batches were combined and mixed

139 prior to biochar application (Sackett et al. 2015). The biochar and P amendments were applied directly

140 to the forest floor litter-fibric-humic (LFH) layer by hand prior to leaf fall and were not tilled into the

141 soils to avoid damaging plant roots. Following application, the experimental plots were left undisturbed

142 until the time of sampling and were covered by three consecutive years of autumn leaf fall. Soil samples

143 were obtained in September 2014 by gently removing a small amount of the forest floor leaf litter at

144 each plot by hand and then collecting duplicate soil cores ( $2 \mathrm{~cm}$ diameter $)$, which were separated into 
upper $(0-5 \mathrm{~cm})$ and lower $(5-15 \mathrm{~cm})$ mineral soil layers. All soil samples were stored at $4{ }^{\circ} \mathrm{C}$ during

146 transport to the laboratory, frozen within $8 \mathrm{~h}$ of collection and freeze-dried. The samples were $1 \mathrm{~mm}$ 147 sieved to remove rocks and visible plant material and homogenized using a mortar and pestle. 148 Preliminary elemental $\mathrm{C}$ and $\mathrm{N}$ analysis and solvent extraction showed similar elemental and biomarker 149 composition, respectively, in control soils across the five blocks (data not shown). As such, composite 150 soil samples were prepared by combining equal amounts of the ten replicate soil cores from the same 151 experimental treatment and sampling depth (4 biochar application rates $\times 2 \mathrm{P}$ application rates $\times 2$ 152 depths, for a total of 16 composites). The composite samples were further homogenized using a mortar 153 and pestle prior to analysis.

155 Soil and biochar characterization

To measure $\mathrm{pH}$, soil or biochar was mixed with deionized $\mathrm{H}_{2} \mathrm{O}(1: 10 \mathrm{w} / \mathrm{v})$ on a reciprocal shaker

for $1 \mathrm{~h}$ (Hendershot et al. 2008), centrifuged, and the $\mathrm{pH}$ of the supernatant was measured using an Accumet Basic pH electrode (Fisher Scientific). Total C and N content were determined by combusting 159 the soil and biochar samples at $950{ }^{\circ} \mathrm{C}$ using a Thermo Flash $2000 \mathrm{CN}$ combustion analyzer and 160 measuring the evolved gases using a thermal conductivity detector. Organic carbon (OC) content was 161 determined by combusting the samples at $475{ }^{\circ} \mathrm{C}$, while the inorganic $\mathrm{C}$ content was calculated as the 162 difference between the total $\mathrm{C}$ and $\mathrm{OC}$ content. Since inorganic $\mathrm{C}$ was not previously detected in 163 Haliburton Forest soils (Mitchell et al. 2015), the percentage of OC was equated to the total C content. 164 Extractable $\mathrm{PO}_{4}{ }^{3-}$ was measured by extracting soils with $0.5 \mathrm{M}$ sodium bicarbonate solution $(1: 20 \mathrm{w} / \mathrm{v}$, $165 \mathrm{pH}=8.5)$ followed by colourimetric detection (Olsen et al. 1954). To examine potential nutrient losses 166 from the amended soils during the three year experiment, the expected increases in soil $\mathrm{C}$ and $\mathrm{N}$ content 167 and extractable $\mathrm{PO}_{4}{ }^{3-}$ concentration at the $0-5 \mathrm{~cm}$ depth were calculated based on the chemical 
168 properties and application rate of the biochar and $\mathrm{P}$ amendments, assuming homogeneous mixing of the 169 amendments into the upper mineral soil.

171 Soil OM biomarker extractions and solution-state ${ }^{1} \mathrm{H}$ NMR spectroscopy analysis

172 Several chemical extraction methods were used to isolate soil OM biomarkers, including a 173 modified Bligh-Dyer extraction protocol to isolate PLFAs (Bligh and Dyer 1959; Frostegård and Bååth 174 1996), solvent extraction to extract unbound lipids and sugars (Otto and Simpson 2005), base hydrolysis 175 to cleave ester-bound wax, cutin and suberin components (Otto and Simpson 2006b) and CuO oxidation 176 to isolate lignin-derived phenols (Hedges and Ertel 1982; Otto and Simpson 2006a). A detailed 177 description of the biomarker extraction and quantification is listed in the Supplementary Material. A 178 sub-sample of the biochar composite used in the amendment study was subjected to all four biomarker 179 extraction protocols in triplicate and did not contain detectable quantities of any OM biomarkers (data 180 not shown). As such, all detected biomarkers are derived from the native soil OM. Whole soil samples 181 were also subjected to HF demineralization (Gonçalves et al. 2003) followed by exhaustive extraction 182 with $\mathrm{NaOH}$ to isolate base-extractable soil OM (Kelleher and Simpson 2006), which was subsequently 183 analyzed using one- and two-dimensional (1-D and 2-D) solution-state ${ }^{1} \mathrm{H}$ NMR spectroscopy (see 184 Supplementary Material). Table 1 summarizes the major soil OM components and parameters which 185 were examined in the upper mineral soil using the biomarker and NMR analyses as well as the 186 corresponding results and their biogeochemical interpretation.

188 Statistical analysis

189 Principal component analysis (PCA) was performed on biomarker concentrations using SPSS 190 Statistics software (v. 20, IBM) to screen for soil microbial community and OM compositional shifts. 191 No data transformation was required since all biomarker data were normally distributed. PCA was 
conducted on the four individual biomarker data sets separately as well as all OM biomarker data combined. To assess the statistical significance of biomarker concentrations and ratios in amended soils relative to the unamended control, and to examine potential interactions between the biochar and $\mathrm{P}$ treatments, a two-way analysis of variance (ANOVA) with Tukey's honest significant difference posthoc test was applied to biomarker data sets using OriginPro software (v. 8.0, OriginLab). A $p$-value $\leq$ 0.05 was considered statistically significant. The ANOVA $F$-statistic and $p$-values obtained for biomarkers in the $0-5 \mathrm{~cm}$ and 5-15 cm depth soils are summarized in Tables S1 and S2, respectively.

\section{Results}

\section{Elemental composition and chemical properties of soils}

The biochar had a near-neutral $\mathrm{pH}=6.73$ and was rich in $\mathrm{OC}(86.7 \%)$ with a small amount of inorganic C also present (0.2\%; Table S3). Sackett et al. (2015) reported that this biochar composite contained extractable $\mathrm{K}^{+}, \mathrm{Ca}^{2+}, \mathrm{Mg}^{2+}$ and $\mathrm{PO}_{4}{ }^{3-}$ ions which could be leached and provide a nutrient source in the soil. Table $\mathrm{S} 4$ lists the soil $\mathrm{pH}$ values as well as the measured and expected total $\mathrm{C}$ and $\mathrm{N}$ content and extractable $\mathrm{PO}_{4}{ }^{3-}$ concentrations of the soil samples. Soil $\mathrm{pH}$ ranged from 4.10-4.57 across all samples and did not show a consistent trend with any amendment or between the two depths. This agrees with two previous studies in which biochar amendment at this site did not alter soil $\mathrm{pH}$ (Noyce et al. 2015; Sackett et al. 2015). At the 0-5 cm depth, the total $\mathrm{C}$ content was elevated in all samples containing biochar relative to the unamended soil, which was anticipated since biochar is a C-rich amendment. The total $\mathrm{C}$ content also increased in the P-fertilized soil. Total $\mathrm{N}$ was higher in all amended $0-5 \mathrm{~cm}$ soil samples relative to the unamended soil. The increases in the total $\mathrm{C}$ and $\mathrm{N}$ content of the amended $0-5 \mathrm{~cm}$ soils were higher than the values expected based on the amount of $\mathrm{C}$ and $\mathrm{N}$ added in the form of biochar. This suggests that soil $\mathrm{C}$ and $\mathrm{N}$ content increased three years postamendment in the upper mineral soil, and indicates that any losses of biochar from the amended soil 
216 plots were minimal (Major et al. 2010). At the 5-15 cm depth, all biochar, P and biochar $+\mathrm{P}$

217 amendments increased soil $\mathrm{C}$ and $\mathrm{N}$ to a similar extent, likely due to increased root growth. Extractable $218 \mathrm{PO}_{4}{ }^{3-}$ concentrations in the $\mathrm{P}$ - and biochar $+\mathrm{P}$-fertilized soils were higher than the unamended soil at 219 both depths, but were only marginally higher than the unamended soil with biochar amendment. The 220 measured extractable $\mathrm{PO}_{4}{ }^{3-}$ concentrations in the biochar-amended soils were in close agreement with 221 the expected values, whereas $\mathrm{PO}_{4}{ }^{3-}$ concentrations were lower than expected in the $\mathrm{P}$ - and biochar $+\mathrm{P}-$ 222 amended soils. This decrease in extractable $\mathrm{PO}_{4}{ }^{3-}$ concentration after three years for all soils amended 223 with $\mathrm{P}$ fertilizer is likely due to $\mathrm{PO}_{4}{ }^{3-}$ uptake by soil microbes and plant biomass and/or leaching into 224 lower soil horizons (Bhatti et al. 1998; Cui et al. 2011).

226 Principal component analysis (PCA) soil OM biomarker PCA scores plots exhibited clear separation between the upper and lower soil horizons along PC1, which explained $91.5 \%$ and $69.0 \%$ of the variance, respectively (Fig. 1). In

231 addition, the upper soil horizon PCA scores showed more variation between the different treatments 232 than the lower soil horizon, suggesting greater differences in the soil microbial community and soil OM 233 composition at the $0-5 \mathrm{~cm}$ depth than at $5-15 \mathrm{~cm}$. The same trend of greater variation in soil $\mathrm{OM}$ 234 composition at the upper depth was also observed for the PCA scores for the individual biomarkers (Fig. 235 S1). Since PCA revealed distinct differences in soil microbial community and OM composition between 236 the treatments, biomarker concentrations and ratios were examined in greater detail to gain more 237 specific insight into these compositional shifts. 
PLFA analysis revealed that biochar, $\mathrm{P}$ and biochar $+\mathrm{P}$ amendment stimulated soil microbial

241 activity and altered the microbial community structure to different extents. A total of 30 PLFAs were 242 identified in the soil samples which were assigned to the following sources (Table S5): Gram-positive 243 bacteria $(i 14: 0, i 15: 0, a 15: 0, i 16: 0, a 16: 0, i 17: 0$ and $a 17: 0)$, Gram-negative bacteria $(16: 1 \omega 7 c, c y 17: 0$,

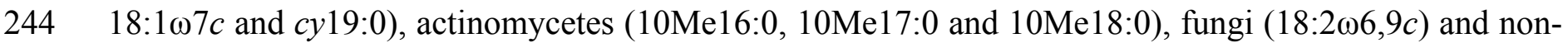
245 specific PLFAs (Zelles 1999). At the 0-5 cm depth, concentrations of Gram-positive, Gram-negative and 246 actinomycete PLFAs increased with nearly all treatments, in most cases significantly (Fig. 2a-c and 247 Table S6). At the same depth, fungal PLFA concentrations increased significantly with biochar and 248 biochar $+\mathrm{P}$ addition but not with $\mathrm{P}$ fertilization (Fig. 2d). At the $5-15 \mathrm{~cm}$ depth, the fungal PLFA 249 concentration decreased significantly with $\mathrm{P}$ fertilization but increased significantly with biochar 250 amendment (Table S7). The ANOVA results showed a significant interaction between biochar and $\mathrm{P}$ in 251 the biochar + P-amended soils for all PLFA biomarkers at both depths, with the exception of the fungal 252 PLFA in the lower soil (Tables S1-S2). Several ratios of PLFAs were calculated to examine microbial 253 community shifts and substrate limitations (Feng and Simpson 2009). At the 0-5 cm depth, the Gram254 negative/Gram-positive ratio decreased with all treatments (Fig. 2e). At both depths, the ratio of 255 bacterial/fungal PLFAs decreased in the biochar and biochar + P-amended soils, in most cases 256 significantly (Fig. 2f and Table S7). Furthermore, the bacterial substrate limitation ratios of $257 c y 17: 0 / 16: 1 \omega 7 c$ and $c y 19: 0 / 18: 1 \omega 7 c$ (Guckert et al. 1986; Kieft et al. 1994; Bossio and Scow 1998) 258 decreased significantly with most amendments in the upper mineral soil (Table S6).

260 Solvent-extractable biomarkers

261 Solvent extraction showed increased concentrations of several plant- and microbial-derived 262 biomarkers as well as shifts in the native OM composition of the amended soils. This extraction yielded 263 several classes of compounds (Table S8), including sugars (monosaccharides and disaccharides), acyclic 
264 aliphatic lipids ( $n$-alkanes, $n$-alkanols and $n$-alkanoic acids) and cyclic aliphatic compounds (steroids 265 and triterpenoids). Statistically significant interactions between the biochar and $\mathrm{P}$ treatments were 266 observed for most solvent-extractable biomarkers in the biochar + P-amended samples at both depths 267 (Tables S1-S2). The sugars identified are found in plants and microbes and thus are not source-specific, 268 but can still provide insight into soil biogeochemical processes (Otto and Simpson 2005). At the 0-5 cm 269 depth, total sugar concentrations increased significantly in the biochar-amended soils and with biochar + $270 \mathrm{P}$ amendment at the $10 \mathrm{t} /$ ha application rate (Fig. 3a and Table S9). At the 5-15 cm depth, P fertilization 271 significantly decreased sugar concentrations whereas biochar $+\mathrm{P}$ addition significantly increased sugars 272 at the $20 \mathrm{t} /$ ha application rate (Table S10). The solvent-extractable acyclic aliphatic lipids included a 273 homologous series of $n$-alkanes, $n$-alkanols and $n$-alkanoic acids which were classified as short-chain $(<$ $\left.274 \mathrm{C}_{20}\right)$ or long-chain $\left(\geq \mathrm{C}_{20}\right)$ compounds that are derived predominantly from microbial and plant sources, 275 respectively (Lichtfouse et al. 1995; Otto and Simpson 2005). Short-chain $n$-alkanoic acid 276 concentrations increased with biochar and biochar $+\mathrm{P}$ addition at the upper depth, in some cases 277 significantly (Fig. 3b). At the same depth, concentrations of long-chain $n$-alkanes, $n$-alkanols and $n$ 278 alkanoic acids increased significantly with most biochar, $\mathrm{P}$ and biochar $+\mathrm{P}$ amendments (Fig. 3c-e). At 279 the lower depth, long-chain $n$-alkane, $n$-alkanol and $n$-alkanoic acid concentrations increased 280 significantly for some treatments but did not show any definitive trends (Table S10). The solvent281 extractable cyclic aliphatic compounds included steroids and triterpenoids derived from microbial and 282 plant sources (Table S8). At the $0-5 \mathrm{~cm}$ depth, total steroid concentrations increased significantly with 283 all amendments (Fig. 3f). Triterpenoid concentrations also increased with all amendments at this depth, 284 in most cases significantly (Fig. 3g). At the 5-15 cm depth, steroid concentrations increased significantly 285 with biochar amendment but decreased significantly with P fertilization (Table S10). The concentration 286 of the fungal-derived steroid ergosterol increased with biochar and biochar $+\mathrm{P}$ amendment at the upper 287 depth, in most cases significantly (Fig. 3h). At the lower depth, ergosterol concentrations increased with 
288 all amendments, significantly in soils with $20 \mathrm{t} /$ ha biochar (Table S10). Ratios of solvent-extractable

289 biomarker concentrations were calculated to further assess changes in soil OM composition and 290 degradation status (Otto and Simpson 2005). The ratio of acyclic/cyclic compounds decreased 291 significantly at the $0-5 \mathrm{~cm}$ depth with all biochar and biochar $+\mathrm{P}$ treatments (Fig. 3i). At the 5-15 cm 292 depth, P fertilization significantly increased the acyclic/cyclic lipid ratio and significantly decreased the 293 ratio of sterols/sterones (Table S10).

Base-hydrolyzable lipids

Base hydrolysis revealed increased concentrations of monomeric components of plant waxes and the biopolymers cutin and suberin in the amended soils. This treatment isolated a series of ester-bound compounds from the soil samples (Table S11), including monomeric components of waxes, cutin and suberin (Kolattukudy and Espelie 1989; Otto and Simpson 2006b). At the 0-5 cm depth, total concentrations of base-hydrolyzable benzyl and phenol compounds increased with all amendments, in 301 some cases significantly (Table S12). Total concentrations of other base-hydrolyzable compounds 302 including $n$-alkanols, $n$-alkanoic acids and $\alpha$-hydroxyalkanoic acids increased with all biochar and $\mathrm{P}$ 303 treatments at both depths, but significantly in only a few instances. Total concentrations of cutin 304 biomarkers, namely the mid-chain-hydroxy $\mathrm{C}_{15}$ and $\mathrm{C}_{16}$ n-alkanoic acids, increased at both depths with 305 all treatments, in several cases significantly (Fig. 4a and Table S13). Similarly, the total concentration of 306 suberin components, including long-chain $\omega$-hydroxyalkanoic acids and $\alpha, \omega$ - $n$-alkanedioic acids, also 307 increased at both depths with most treatments (Fig. 4b). Two-way ANOVA revealed a statistically 308 significant interaction between biochar and P for most base-hydrolyzable biomarkers at the lower depth, 309 but only in a few instances for the upper soil (Tables S1-S2). The ratio of suberin/cutin biomarkers (Otto 310 and Simpson 2006b) decreased slightly with all treatments at the upper depth (Fig. 4c), signalling a shift 311 toward a greater proportion of cutin components in the amended soils. Cutin and suberin degradation 
312 ratios $\left(\omega-\mathrm{C}_{16} / \Sigma \mathrm{C}_{16}, \omega-\mathrm{C}_{18} / \Sigma \mathrm{C}_{18}\right.$ and $\left.\Sigma \mathrm{mid} / \Sigma \mathrm{SC}\right)$ did not change at either depth (Tables S12-S13),

313 indicating no enhanced cutin or suberin degradation during the study.

315 Lignin-derived phenols

316 Alkaline $\mathrm{CuO}$ oxidation showed increased concentrations of lignin-derived phenol monomers 317 and dimers as well as a shift in the relative proportion of these components in the biochar and biochar + 318 P-amended soils. This treatment yielded several types of lignin-derived compounds (Hedges and Ertel 319 1982; Otto and Simpson 2006a) including phenol monomers (vanillyl, syringyl and cinnamyl classes) 320 and dimers $\left(5,5^{\prime}, \alpha, 1\right.$-monoketone, $\alpha, 2$-methyl and $\beta, 1$-diketone classes; Table S14). Several benzyl 321 compounds were also identified which may be derived from lignin as well as other sources such as 322 protein (Goñi et al. 2000; Otto and Simpson 2006a). At the 0-5 cm depth, total concentrations of benzyl 323 compounds, phenol monomers (denoted as $\Sigma \mathrm{VSC}$ ) and phenol dimers increased significantly in the 324 biochar-amended soils at the 5 and 20 t/ha application rates, while biochar $+\mathrm{P}$ amendment significantly 325 increased $\Sigma \mathrm{VSC}$ at the $10 \mathrm{t} / \mathrm{ha}$ application rate (Fig. $4 \mathrm{~d}$,e and Table S15). At the 5-15 $\mathrm{cm}$ depth, total 326 concentrations of benzyl compounds, $\Sigma$ VSC and dimers decreased significantly with $\mathrm{P}$ and biochar $+\mathrm{P}$ 327 amendment (Table S16). A statistically significant interaction was observed between the biochar and P 328 treatments for most lignin-derived compounds in the biochar + P-amended soils at the upper depth, 329 whereas this interaction was significant in only a few cases at the lower depth (Tables S1-S2). Ratios of 330 lignin-derived phenol compounds were calculated to assess the lignin degradation status and the relative 331 proportion of monomeric and dimeric lignin components in the soils (Ertel and Hedges 1984; Hedges et 332 al. 1988; Goñi and Hedges 1992; Otto and Simpson 2006a). At the upper depth, acid/aldehyde ratios did 333 not change significantly with any treatment (Table S15). At the lower depth, the dehydrodivanillic $334 \mathrm{acid} /$ dehydrodivanillin ratio increased significantly in the 10 and 20 t/ha biochar $+\mathrm{P}$-amended soils 335 (Table S16). The ratio of lignin-derived phenol monomers/dimers increased with P fertilization and to a 
336 greater extent with biochar and biochar $+\mathrm{P}$ amendment at the $0-5 \mathrm{~cm}$ depth, in several cases

337 significantly (Fig. 4f). Significant increases in this ratio were also seen with most treatments at the 5-15 338 cm depth (Table S16).

Solution-state NMR spectroscopy

Solution-state ${ }^{1} \mathrm{H}$ NMR analysis of soil base extracts revealed decreased proportions of labile $O$ alkyl OM and increased proportions of more recalcitrant alkyl C-rich OM in the amended soils.

Representative 1-D and 2-D solution-state NMR spectra of the extracts with integrated areas labelled are shown in Fig. 5 and the integration results are summarized in Tables S17-S19. At the 0-5 cm depth, 1-D

${ }^{1} \mathrm{H}$ NMR analysis showed that the relative proportion of aliphatic components such as lipids, waxes, cutin and suberin increased at the $20 \mathrm{t} /$ ha biochar application rate both with and without $\mathrm{P}$ fertilization (Table S17). The proportion of $N$ - and $O$-substituted aliphatic components such as lipids, amino acids, peptidoglycan and chitin increased marginally with $\mathrm{P}$ fertilization, but decreased with biochar and biochar $+\mathrm{P}$ amendment. A slight decrease in $O$-alkyl constituents including carbohydrates, peptides and amino acids was observed in the soils containing $20 \mathrm{t} / \mathrm{ha}$ biochar, while the proportions of aromatic and 351 phenolic components such as lignin and aromatic amino acids increased in the same samples. At the 5$15 \mathrm{~cm}$ depth, $\mathrm{P}$ fertilization increased the amount of $N$ - and $O$-substituted aliphatic components and decreased the amount of $O$-alkyl compounds. 1-D DE ${ }^{1} \mathrm{H}$ NMR was used to analyze the composition of macromolecules and rigid OM components as this technique attenuates the signals from small molecules that diffuse quickly in solution (Simpson et al. 2007). Increased proportions of macromolecular aliphatic constituents such as waxes, cutin and suberin were observed with all treatments at both depths, with the 358 alkyl structures such as carbohydrates, peptides and protein was seen at the $0-5 \mathrm{~cm}$ depth with biochar 359 and biochar $+\mathrm{P}$ amendment. At the same depth, increased proportions of aromatic and phenolic 
components were observed at the 10 and 20 t/ha application rates, while a similar increase was noted at

361 the 5-15 cm depth but only with $20 \mathrm{t} /$ ha biochar addition. 2-D ${ }^{1} \mathrm{H}-{ }^{13} \mathrm{C}$ HSQC NMR spectroscopy was 362 used to confirm 1-D spectral assignments as this technique provides enhanced resolution of OM 363 components due to the greater spectral dispersion of the ${ }^{13} \mathrm{C}$ nucleus (Simpson et al. 2011). Changes in 364 the relative proportions of specific OM functionalities were assessed by calculating normalized area 365 ratios for defined regions of the HSQC spectra (Table S19 and Fig. 5c). At the 0-5 cm depth, the relative 366 proportion of aliphatic constituents rich in $\mathrm{CH}_{2}$ and $\mathrm{CH}_{3}$ groups increased with all treatments compared 367 to the unamended soil. Increased proportions of peptide-derived components such as $\alpha$-protons and the 368 amino acids phenylalanine and tyrosine as well as higher proportions of lignin methoxy groups were 369 also observed at this depth with most treatments, in particular at the two higher biochar application rates.

370 Carbohydrate signals including $\mathrm{CH}, \mathrm{CH}_{2}$ and anomeric groups decreased with most treatments at both 371 depths, especially at the 10 and 20 t/ha biochar application rates both with and without $\mathrm{P}$ fertilization.

\section{Discussion}

374 Biochar and $\mathrm{P}$ amendment stimulated soil microbial activity and altered the soil microbial community 375 composition resulted in some similar but also contrasting changes in soil microbial activity three years postamendment. The increased concentrations of PLFAs specific to Gram-positive and Gram-negative bacteria and actinomycetes that were observed in the upper mineral soil $(0-5 \mathrm{~cm})$ signify that bacterial activity was stimulated by most biochar and P amendments. However, the lack of significant differences 381 between the treatments indicates that bacterial activity was not preferentially stimulated by one 382 amendment over the others. The higher concentrations of microbial-derived short-chain $n$-alkanoic acids 
increased microbial-derived inputs to the amended soils. Previous studies have also reported stimulated 385 bacterial activity following biochar amendment in soil using PLFA analysis (Steinbeiss et al. 2009; 386 Santos et al. 2012; Gomez et al. 2014; Prayogo et al. 2014; Watzinger et al. 2014; Ameloot et al. 2015; 387 Mitchell et al. 2015). This increase in bacterial activity over time may have arisen from biochar-induced improvements to soil properties such as nutrient availability and macroporous habitats for microbes 389 (Mukherjee and Zimmerman 2013; Brewer et al. 2014; Gul et al. 2015). Since biochar, P and biochar + 390 P stimulated bacterial activity to a similar extent, this enhanced activity was likely the result of increased 391 soil nutrient availability rather than the presence of the biochar particles as a physical substrate. This is 392 supported by decreases in the PLFA stress ratios, which indicated that bacteria experienced less 393 substrate constraints in the amended soils (Guckert et al. 1986; Kieft et al. 1994; Bossio and Scow 1998). Lower ratios of Gram-negative/Gram-positive bacterial PLFAs at the $0-5 \mathrm{~cm}$ depth with all observed a bacterial community shift toward Gram-positive bacteria during a short-term amendment study using a different soil type and biochar (Ameloot et al. 2013). Gul et al. (2015) proposed that 401 Gram-positive bacteria preferentially utilize biochar-derived C as an energy source compared to Gram402 negative bacteria since Gram-positive bacteria have been found to selectively degrade more recalcitrant 403 forms of soil OM. For example, one study reported that the activity of Gram-positive bacteria increased 404 with soil depth as concentrations of recalcitrant OM components increased (Fierer et al. 2003). Two 405 previous biochar amendment studies also reported that Gram-positive bacteria incorporated biochar406 derived $\mathrm{C}$ into their cell membrane lipids (Santos et al. 2012; Farrell et al. 2013). Given that bacteria in 407 the surface mineral soil would be in close proximity to the amended biochar particles, a shift toward 
408 Gram-positive bacteria could be expected at this depth. In addition, a shift toward Gram-positive 409 bacteria was not observed in the lower soil layer which did not contain visible biochar particles. 410 Stimulation of Gram-positive bacteria by P fertilization of forest soils has also been reported previously, 411 albeit primarily in P-limited tropical ecosystems (Krashevska et al. 2010; Fanin et al. 2015). 412 Collectively, our results suggest that biochar, $\mathrm{P}$ and biochar $+\mathrm{P}$ addition at this site favoured Gram413 positive bacteria and caused localized shifts in the soil bacterial community structure.

414 The fungal PLFA $(18: 2 \omega 6,9 c)$ and ergosterol data indicated that fungal activity in the upper 415 mineral soil was stimulated by biochar and biochar $+\mathrm{P}$ addition but not by $\mathrm{P}$ fertilization alone, in 416 contrast with bacterial activity which increased with all amendments at this depth. This suggests that 417 fungal activity may not be dependent on soil $\mathrm{P}$ concentrations to the same extent as bacteria, and that 418 fungi responded favourably to biochar addition. Previous studies have reported that fungi can colonize 419 biochar particles and macropores via their hyphal networks, potentially allowing access to a 420 concentrated source of biochar-derived nutrients and residual pyrolysis compounds as well as a physical 421 substrate to support growth (Ascough et al. 2010; Spokas et al. 2011; Hammer et al. 2014; Jaafar et al. 422 2014). The fungal PLFA and ergosterol data also showed that fungal activity was stimulated in the lower 423 mineral soil when biochar was applied to the forest floor. Fungal hyphae may have accessed biochar 424 particles at the soil surface which would be inaccessible to bacteria in the deeper soil. Conversely, 425 fungal activity decreased at the lower depth with $\mathrm{P}$ fertilization. This was likely due to a reduction in 426 mycorrhizal interactions with plant roots due to increased P availability (van der Heijden et al. 2008), 427 and is consistent with a previous $\mathrm{P}$ fertilization experiment that was conducted at this forest site (Noyce 428 et al. 2015). The decreasing bacterial/fungal PLFA ratio at both soil depths with biochar and biochar $+\mathrm{P}$ 429 amendment indicates that fungal activity was stimulated to a greater extent than bacterial activity, and 430 that the microbial community shifted toward a greater proportion of fungi vs. bacteria with these 431 treatments. This suggests that the modified soil conditions with biochar were more favourable for fungi 
than bacteria, and agrees with two previous studies which also observed preferential stimulation of soil

433 fungi in response to long-term biochar addition (Steinbeiss et al. 2009; Farrell et al. 2013). The shifts in

434 microbial community composition observed with the biochar and biochar $+\mathrm{P}$ amendments may have

435 ecological implications as microbes play a critical role in soil processes such as OM decomposition, 436 nutrient cycling and greenhouse gas production, among others (Thies and Rillig 2009). As such, 437 potential shifts in soil microbial communities should be carefully assessed prior to large-scale biochar 438 amendment of forest soils.

Biochar and $\mathrm{P}$ amendment altered the native soil OM molecular composition accumulated in the $0-5 \mathrm{~cm}$ amended soils during the three-year period. This included solvent-extractable short and long-chain aliphatic lipids, sugars, steroids and triterpenoids, base-hydrolyzable cutin and suberin components, as well as lignin-derived phenol monomers and dimers. Higher proportions of alkyl polymethylene and lignin methoxy group resonances in the solution-state NMR spectra of the amended soil base extracts further confirmed the increased inputs of plant-derived OM. Since the PLFA results 447 indicated that bacterial activity in the upper mineral soil was stimulated by $\mathrm{P}$ fertilization, we propose that enhanced microbial decomposition of forest floor litter resulted in increased inputs of extractable 449 plant- and microbial-derived biomarkers in the P-fertilized soil. An increase in the total C and N content 450 of the P-amended soil relative to the unamended soil supports this potential accumulation of soil OM 451 components. For soils amended with biochar and biochar $+\mathrm{P}$, the higher extractable biomarker 452 concentrations could be due to increased plant and microbial inputs as well as the sorptive retention of 453 biomarker compounds by biochar particles, which have a strong sorption capacity for OM (Uchimiya et 454 al. 2010; Smebye et al. 2016). Sorption to biochar may lower the bioavailability and thus the 455 susceptibility of these OM components to microbial degradation, potentially increasing their soil 
residence time (Chenu and Plante 2006; Mikutta et al. 2007) and resulting in higher concentrations of extractable biomarkers. Collectively, higher OM inputs and the sorptive preservation of OM on biochar particles may explain why the total $\mathrm{C}$ and $\mathrm{N}$ content of the biochar and biochar $+\mathrm{P}$-amended soils were higher than predicted based on the amount of $\mathrm{C}$ and $\mathrm{N}$ added in the form of biochar. While the biochar and biochar $+\mathrm{P}$ treatments increased the concentration of most extractable soil OM biomarkers, $\mathrm{P}$ 461 fertilization led to an accumulation of primarily slower-degrading OM components such as steroids, 462 triterpenoids, cutin and suberin. A previous $\mathrm{P}$ fertilization experiment at the same forest demonstrated 463 that concentrations of soil $\mathrm{PO}_{4}{ }^{3-}, \mathrm{K}^{+}, \mathrm{Ca}^{2+}$ and $\mathrm{Mg}^{2+}$ increased within 2-6 weeks of $\mathrm{P}$ fertilization at the 464 same application rate (Sackett et al. 2015). This increased nutrient availability may have stimulated 465 microbial activity and induced soil priming earlier in the study, leading to increased soil OM 466 degradation and preferentially mineralizing more labile OM components such as sugars. This may 467 explain why the concentrations of the more recalcitrant compounds increased after three years in the P468 fertilized plots, while concentrations of more labile biomarkers were unchanged.

Analysis of soil OM biomarker ratios and solution-state NMR data revealed several potential 470 shifts in the OM composition of the amended soils at the $0-5 \mathrm{~cm}$ depth. Although both acyclic and cyclic 471 aliphatic lipids accumulated, a decreased acyclic/cyclic lipid ratio with all biochar and biochar $+\mathrm{P}$ 472 treatments indicated an OM compositional shift toward a greater proportion of steroid and triterpenoid 473 compounds in these soils. Stimulated microbial activity may have resulted in the preferential 474 degradation of acyclic aliphatic lipids such as $n$-alkanes, $n$-alkanols and $n$-alkanoic acids compared to 475 cyclic lipids, which may be more inherently resistant to degradation due to their molecular structure 476 (von Lützow et al. 2006). For example, plant sterols are commonly found in soils in an unaltered state 477 and in greater abundance than their sterone oxidation products (Otto and Simpson 2005). The 478 preferential sorption of cyclic compounds to biochar particles may also account for their relative 479 preservation compared to the acyclic aliphatic lipids, especially since this OM compositional shift was 
not observed with $\mathrm{P}$ fertilization. $\mathrm{CuO}$ oxidation revealed a shift toward a greater proportion of 481 extractable lignin-derived phenol monomers vs. dimers in the biochar- and biochar + P-amended soils at 482 the upper depth. Lignin is bound to hemicellulose and cellulose in plant cell walls, forming the ligno483 cellulose complex (Sjöström 1993), and the degradation of ligno-cellulose in soil is believed to be 484 initiated primarily by fungi as well as some species of bacteria (Antai and Crawford 1981; Hedges et al. 485 1988; Orth et al. 1993). These microbes are capable of cleaving lignin from the polysaccharide, which 486 may in turn increase substrate accessibility to other lignin-degrading fungi and bacteria (Tuomela et al. 487 2000). Since the PLFA and ergosterol data suggested that fungal activity was stimulated by the biochar 488 and biochar $+\mathrm{P}$ treatments, increases in the lignin monomer/dimer ratio may reflect the preferential 489 degradation of dimeric lignin subunits by microbes (Goñi et al. 1993), or changes in the relative extractability of lignin sidechains due to structural alteration of the lignin macromolecule. Solution-state 491 NMR analysis of soil base extracts showed an OM compositional shift toward a lower proportion of 492 carbohydrate-derived components and a higher proportion of alkyl and lignin constituents with all 493 amendments. Decreased proportions of carbohydrates may indicate enhanced microbial degradation of 494 polysaccharides such as cellulose, which is supported by the higher concentrations of solvent-extractable 495 sugar monomers that were observed in the amended soils. The concomitant increases in alkyl and lignin496 derived compounds are consistent with the accumulation of aliphatic lipids and lignin phenols that were 497 detected using biomarker analysis, and with a previous laboratory biochar incubation study conducted 498 using soil from this forest (Mitchell et al. 2016).

499 Soil OM composition in the biochar-amended soils did not vary as greatly from the control at the $500 \quad 5-15 \mathrm{~cm}$ depth as in the surface mineral soil, likely because the biochar was not thoroughly mixed into 501 the lower depth upon application. However, lower concentrations of sugars, long-chain $n$-alkanes and $n$ 502 alkanoic acids, steroids and triterpenoids as well as lignin-derived phenols were found in the lower 503 mineral soil with $\mathrm{P}$ fertilization. The sterol/sterone ratio also decreased in this soil, which indicates that 
sterols were at a more advanced stage of oxidation. These findings suggest increased soil OM

505 degradation in the lower soil horizon three years post-amendment, but the PLFA data indicated that 506 microbial activity in the P-amended soil was similar to or lower than the unamended soil at this depth. 507 The decrease in OM components may be explained by soil priming shortly after the P fertilizer was 508 added. P leaching downward from the surface soil may have stimulated microbial activity (Cleveland et 509 al. 2002; Zhu et al. 2015) and led to accelerated OM decomposition in the lower mineral soil, resulting 510 in a decrease in the concentration of specific OM components. Microbial activity in the 5-15 cm soil 511 may have then decreased to the observed levels once amended $\mathrm{P}$ concentrations were depleted by 512 leaching and/or incorporation into soil organisms (Bhatti et al. 1998; Cui et al. 2011).

514 Biochar and P fertilizer as prospective soil amendments in P-limited managed forests This study demonstrated that biochar, $\mathrm{P}$ and biochar $+\mathrm{P}$ amendment in a $\mathrm{P}$-limited temperate 516 forest for three years increased soil nutrient availability, altering the soil microbial community and 517 native soil OM composition as hypothesized. In several instances, biochar, $\mathrm{P}$ and biochar $+\mathrm{P}$ addition 518 led to similar changes in these soil properties. For example, all three types of amendments stimulated 519 soil bacterial activity and increased the concentration of extractable plant-derived soil OM biomarkers, 520 likely due to the enhanced breakdown of forest floor litter by microbes. However, several important 521 differences were also observed between the biochar and $\mathrm{P}$ amendments, which may have implications 522 for soil $\mathrm{C}$ sequestration and nutrient supplementation. First, P fertilization appears to have induced soil 523 priming since labile OM components such as solvent-extractable sugars did not accumulate in this soil, 524 whereas labile OM constituents accumulated with biochar amendment. Although P fertilization may 525 increase the availability of limiting soil nutrients, fertilizer application may be disadvantageous in the 526 long-term from a $\mathrm{C}$ sequestration perspective as priming may enhance soil $\mathrm{OM}$ decomposition and soil $527 \mathrm{CO}_{2}$ efflux (Kuzyakov et al. 2000; Keith et al. 2011; Luo et al. 2011; Zimmerman et al. 2011). Secondly, 
528 soil OM compositional shifts toward a higher concentration of cyclic vs. acyclic lipids and lignin529 derived phenol monomers vs. dimers were observed with biochar amendment but not with $\mathrm{P}$ 530 fertilization. These compositional shifts suggest that biochar amendment may result in the preferential 531 accumulation of specific OM components. This may be due to the sorption of OM onto biochar particles 532 (Smebye et al. 2016), which could increase soil C storage but may also alter soil C biogeochemical 533 cycling. Thirdly, biochar amendment stimulated soil fungal activity and shifted the microbial 534 community toward a greater proportion of fungi over bacteria, which was not observed with $\mathrm{P}$ 535 fertilization alone. Since fungi are important decomposers in soil, long-term microbial community shifts 536 toward fungi with biochar addition may increase soil nutrient availability (McTiernan et al. 1997; 537 Kalbitz et al. 2000; Lehmann et al. 2011). However, increased fungal activity could further shift the 538 native soil OM composition, and it is unclear whether biochar amendment stimulated the activity of 539 fungi which are plant pathogens (Elad et al. 2010; Graber et al. 2014). In most cases, the biochar and 540 biochar $+\mathrm{P}$ amendments enhanced microbial activity and altered the native soil OM composition to a 541 similar extent. Although the soils at this site are reported to be P-deficient (Gradowski and Thomas 542 2006; Casson et al. 2012; Sackett et al. 2015), it appears that the amount of P and other ionic nutrients 543 supplied by biochar amendment was sufficient to alleviate soil nutrient deficiencies and enhance 544 microbial activity. Overall, it may be advantageous to use biochar as an amendment in P-limited 545 managed forests as biochar provides a sustained source and sorbent of nutrients without increasing soil 546 priming. However, long-term monitoring of nutrient availability in the biochar-amended soils is needed 547 to further assess the nutrient supplementation capability of biochar in this forest ecosystem over longer 548 time scales. Furthermore, potential biochar-induced changes in soil OM biogeochemistry should be 549 studied in other managed forests to better understand the ramifications of biochar addition prior to the 550 amendment of unmanaged forests. 
This work was funded by a Strategic Projects Grant from the Natural Sciences and Engineering

Research Council (NSERC) of Canada. P.J.M. thanks NSERC for a Postgraduate Scholarship, H.

Masoom and K. Gaynor for assistance with soil sampling, G. Noyce and N. Wagner for advice on

statistics, and the Haliburton Forest and Wild Life Reserve Ltd. for study site access.

\section{7}

\section{Electronic supplementary material}

The online version of this article contains supplementary material, which is available to

authorized users.

\section{References}

Ameloot N, De Neve S, Jegajeevagan K, Yildiz G, Buchan D, Funkuin YN, Prins W, Bouckaert L, Sleutel S (2013) Short-term $\mathrm{CO}_{2}$ and $\mathrm{N}_{2} \mathrm{O}$ emissions and microbial properties of biochar amended sandy loam soils. Soil Biol Biochem 57:401-410

Ameloot N, Sleutel S, Das KC, Kanagaratnam J, De Neve S (2015) Biochar amendment to soils with contrasting organic matter level: Effects on $\mathrm{N}$ mineralization and biological soil properties. GCB Bioenergy 7:135-144

Antai SP, Crawford DL (1981) Degradation of softwood, hardwood, and grass lignocelluloses by two Streptomyces strains. Appl Environ Microbiol 42:378-380

Ascough PL, Sturrock CJ, Bird MI (2010) Investigation of growth responses in saprophytic fungi to charred biomass. Isotopes Environ Health Stud 46:64-77

Bergh J, Nilsson U, Allen H, Johansson U, Fahlvik N (2014) Long-term responses of Scots pine and Norway spruce stands in Sweden to repeated fertilization and thinning. For Ecol Manage 320:118128

Bhatti JS, Comerford NB, Johnston CT (1998) Influence of oxalate and soil organic matter on sorption and desorption of phosphate onto a spodic horizon. Soil Sci Soc Am J 62:1089-1095

Biederman LA, Harpole WS (2013) Biochar and its effects on plant productivity and nutrient cycling: A meta-analysis. GCB Bioenergy 5:202-214

Binkley D, Burnham H, Lee Allen H (1999) Water quality impacts of forest fertilization with nitrogen and phosphorus. For Ecol Manage 121:191-213

Bligh EG, Dyer WJ (1959) A rapid method of total lipid extraction and purification. Can J Biochem Physiol 37:911-917

Bossio DA, Scow KM (1998) Impacts of carbon and flooding on soil microbial communities: Phospholipid fatty acid profiles and substrate utilization patterns. Microb Ecol 35:265-278

Brewer CE, Chuang VJ, Masiello CA, Gonnermann H, Gao X, Dugan B, Driver LE, Panzacchi P, Zygourakis K, Davies CA (2014) New approaches to measuring biochar density and porosity. Biomass Bioenergy 66:176-185 
Brockley RP (2007) Effects of 12 years of repeated fertilization on the foliar nutrition and growth of young lodgepole pine in the central interior of British Columbia. Can J For Res 37:2115-2129

Case SDC, McNamara NP, Reay DS, Whitaker J (2012) The effect of biochar addition on $\mathrm{N}_{2} \mathrm{O}$ and $\mathrm{CO}_{2}$ emissions from a sandy loam soil - The role of soil aeration. Soil Biol Biochem 51:125-134

Casson NJ, Eimers MC, Watmough SA (2012) An assessment of the nutrient status of sugar maple in Ontario: Indications of phosphorus limitation. Environ Monit Assess 184:5917-5927

Chenu C, Plante AT (2006) Clay-sized organo-mineral complexes in a cultivation chronosequence: Revisiting the concept of the 'primary organo-mineral complex'. Eur J Soil Sci 57:596-607

Cleveland CC, Townsend AR, Schmidt SK (2002) Phosphorus limitation of microbial processes in moist tropical forests: Evidence from short-term laboratory incubations and field studies. Ecosystems 5:680-691

Cole DW (1995) Soil nutrient supply in natural and managed forests. Plant Soil 168-169:43-53

Cross A, Sohi SP (2011) The priming potential of biochar products in relation to labile carbon contents and soil organic matter status. Soil Biol Biochem 43:2127-2134

Cui H, Wang MK, Fu M, Ci E (2011) Enhancing phosphorus availability in phosphorus-fertilized zones by reducing phosphate adsorbed on ferrihydrite using rice straw-derived biochar. J Soils Sediments 11:1135-1141

Elad Y, David DR, Harel YM, Borenshtein M, Kalifa HB, Silber A, Graber ER (2010) Induction of systemic resistance in plants by biochar, a soil-applied carbon sequestering agent. Phytopathology 100:913-921

Environment Canada (2005) Canadian Acid Deposition Science Assessment 2004. Environment Canada. Retrieved from: http://publications.gc.ca/site/eng/9.688243/publication.html

Environment Canada (2015) Climate normals and averages, 1981-2010. Environment Canada. Retrieved from: http://climate.weather.gc.ca/climate_normals/index_e.html

Ertel JR, Hedges JI (1984) The lignin component of humic substances: Distribution among soil and sedimentary humic, fulvic, and base-insoluble fractions. Geochim Cosmochim Acta 48:2065-2074

Fanin N, Hättenschwiler S, Schimann H, Fromin N (2015) Interactive effects of C, N and P fertilization on soil microbial community structure and function in an Amazonian rain forest. Funct Ecol 29:140-150

Farrell M, Kuhn TK, Macdonald LM, Maddern TM, Murphy DV, Hall PA, Singh BP, Baumann K, Krull ES, Baldock JA (2013) Microbial utilisation of biochar-derived carbon. Sci Total Environ 465:288-297

Feng X, Simpson MJ (2009) Temperature and substrate controls on microbial phospholipid fatty acid composition during incubation of grassland soils contrasting in organic matter quality. Soil Biol Biochem 41:804-812

Feng X, Simpson MJ (2011) Molecular-level methods for monitoring soil organic matter responses to global climate change. J Environ Monit 13:1246-1254

Fenn ME, Poth MA, Aber JD, Baron JS, Bormann BT, Johnson DW, Lemly AD, McNulty SG, Ryan DF, Stottlemyer R (1998) Nitrogen excess in North American ecosystems: Predisposing factors, ecosystem responses, and management strategies. Ecol Appl 8:706-733

Fierer N, Schimel JP, Holden PA (2003) Variations in microbial community composition through two soil depth profiles. Soil Biol Biochem 35:167-176

Frostegård A, Bååth E (1996) The use of phospholipid fatty acid analysis to estimate bacterial and fungal biomass in soil. Biol Fertil Soils 22:59-65

Gomez JD, Denef K, Stewart CE, Zheng J, Cotrufo MF (2014) Biochar addition rate influences soil microbial abundance and activity in temperate soils. Eur J Soil Sci 65:28-39 
Gonçalves CN, Dalmolin RSD, Dick DP, Knicker H, Klamt E, Kögel-Knabner I (2003) The effect of $10 \% \mathrm{HF}$ treatment on the resolution of CPMAS ${ }^{13} \mathrm{C}$ NMR spectra and on the quality of organic matter in Ferralsols. Geoderma 116:373-392

Goñi MA, Hedges JI (1992) Lignin dimers: Structures, distribution, and potential geochemical applications. Geochim Cosmochim Acta 56:4025-4043

Goñi MA, Nelson B, Blanchette RA, Hedges JI (1993) Fungal degradation of wood lignins: Geochemical perspectives from CuO-derived phenolic dimers and monomers. Geochim Cosmochim Acta 57:3985-4002

Goñi MA, Yunker MB, MacDonald RW, Eglinton TI (2000) Distribution and sources of organic biomarkers in arctic sediments from the Mackenzie River and Beaufort Shelf. Mar Chem 71:23-51

Graber ER, Frenkel O, Jaiswal AK, Elad Y (2014) How may biochar influence severity of diseases caused by soilborne pathogens? Carbon Manage 5:169-183

Gradowski T, Thomas SC (2006) Phosphorus limitation of sugar maple growth in central Ontario. For Ecol Manage 226:104-109

Gradowski T, Thomas SC (2008) Responses of Acer saccharum canopy trees and saplings to P, K and lime additions under high $\mathrm{N}$ deposition. Tree Physiol 28:173-185

Gress SE, Nichols TD, Northcraft CC, Peterjohn WT (2007) Nutrient limitation in soils exhibiting differing nitrogen availabilities: What lies beyond nitrogen saturation? Ecology 88:119-130

Guckert JB, Hood MA, White DC (1986) Phospholipid ester-linked fatty acid profile changes during nutrient deprivation of Vibrio cholerae: Increases in the trans/cis ratio and proportions of cyclopropyl fatty acids. Appl Environ Microbiol 52:794-801

Gul S, Whalen JK, Thomas BW, Sachdeva V, Deng H (2015) Physico-chemical properties and microbial responses in biochar-amended soils: Mechanisms and future directions. Agric Ecosyst Environ 206:46-59

Gundale MJ, DeLuca TH (2006) Temperature and source material influence ecological attributes of ponderosa pine and Douglas-fir charcoal. For Ecol Manage 231:86-93

Hammer EC, Balogh-Brunstad Z, Jakobsen I, Olsson PA, Stipp SLS, Rillig MC (2014) A mycorrhizal fungus grows on biochar and captures phosphorus from its surfaces. Soil Biol Biochem 77:252260

Harwood JL, Russell NJ (1984) Lipids in Plants and Microbes. George Allen and Unwin, London, UK

Hedges JI, Ertel JR (1982) Characterization of lignin by gas capillary chromatography of cupric oxide oxidation products. Anal Chem 54:174-178

Hedges JI, Blanchette RA, Weliky K, Devol AH (1988) Effects of fungal degradation on the CuO oxidation products of lignin: A controlled laboratory study. Geochim Cosmochim Acta 52:27172726

Hedwall PO, Nordin A, Brunet J, Bergh J (2010) Compositional changes of forest-floor vegetation in young stands of Norway spruce as an effect of repeated fertilisation. For Ecol Manage 259:24182425

Hedwall PO, Gong P, Ingerslev M, Bergh J (2014) Fertilization in northern forests - biological, economic and environmental constraints and possibilities. Scand J For Res 29:301-311

Hendershot WH, Lalande H, Duquette M (2008) Soil reaction and exchangeable acidity. In: Carter MR, Gregorich EG (eds) Soil Sampling and Methods of Analysis, 2nd edn. CRC Press, Boca Raton, FL, USA, pp 173-178

Jaafar NM, Clode PL, Abbott LK (2014) Microscopy observations of habitable space in biochar for colonization by fungal hyphae from soil. J Integr Agric 13:483-490

Jeffery S, Verheijen FGA, van der Velde M, Bastos AC (2011) A quantitative review of the effects of biochar application to soils on crop productivity using meta-analysis. Agric Ecosyst Environ 144:175-187 
Kalbitz K, Solinger S, Park JH, Michalzik B, Matzner E (2000) Controls on the dynamics of dissolved organic matter in soils: A review. Soil Sci 165:277-304

Keith A, Singh B, Singh BP (2011) Interactive priming of biochar and labile organic matter mineralization in a smectite-rich soil. Environ Sci Technol 45:9611-9618

Kelleher BP, Simpson AJ (2006) Humic substances in soils: Are they really chemically distinct? Environ Sci Technol 40:4605-4611

Kieft TL, Ringelberg DB, White DC (1994) Changes in ester-linked phospholipid fatty acid profiles of subsurface bacteria during starvation and desiccation in a porous medium. Appl Environ Microbiol 60:3292-3299

Kolattukudy PE, Espelie KE (1989) Chemistry, biochemistry and function of suberin and associated waxes. In: Rowe JW (ed) Natural Products of Woody Plants. Springer, Berlin, Germany, pp 304367

Krashevska V, Maraun M, Ruess L, Scheu S (2010) Carbon and nutrient limitation of soil microorganisms and microbial grazers in a tropical montane rain forest. Oikos 119:1020-1028

Kuzyakov Y, Friedel JK, Stahr K (2000) Review of mechanisms and quantification of priming effects. Soil Biol Biochem 32:1485-1498

Lal R (2008) Sequestration of atmospheric $\mathrm{CO}_{2}$ in global carbon pools. Energy Environ Sci 1:86-100

Lehmann J, Joseph S (2009) Biochar for environmental management: An introduction. In: Lehmann J, Joseph S (eds) Biochar for Environmental Management: Science and Technology. Earthscan, London, UK, pp 1-12

Lehmann J, Rillig MC, Thies J, Masiello CA, Hockaday WC, Crowley D (2011) Biochar effects on soil biota - A review. Soil Biol Biochem 43:1812-1836

Lehmann J (2007) A handful of carbon. Nature 447:143-144

Lichtfouse É, Berthier G, Houot S, Barriuso E, Bergheaud V, Vallaeys T (1995) Stable carbon isotope evidence for the microbial origin of $\mathrm{C}_{14}-\mathrm{C}_{18} n$-alkanoic acids in soils. Org Geochem 23:849-852

Luo Y, Durenkamp M, De Nobili M, Lin Q, Brookes PC (2011) Short term soil priming effects and the mineralisation of biochar following its incorporation to soils of different $\mathrm{pH}$. Soil Biol Biochem 43:2304-2314

Maestrini B, Herrmann AM, Nannipieri P, Schmidt MWI, Abiven S (2014) Ryegrass-derived pyrogenic organic matter changes organic carbon and nitrogen mineralization in a temperate forest soil. Soil Biol Biochem 69:291-301

Major J, Lehmann J, Rondon M, Goodale C (2010) Fate of soil-applied black carbon: Downward migration, leaching and soil respiration. Global Change Biol 16:1366-1379

McCormack SA, Ostle N, Bardgett RD, Hopkins DW, Vanbergen AJ (2013) Biochar in bioenergy cropping systems: Impacts on soil faunal communities and linked ecosystem processes. GCB Bioenergy 5:81-95

McTiernan KB, Ineson P, Coward PA (1997) Respiration and nutrient release from tree leaf litter mixtures. Oikos 78:527-538

Mikutta R, Mikutta C, Kalbitz K, Scheel T, Kaiser K, Jahn R (2007) Biodegradation of forest floor organic matter bound to minerals via different binding mechanisms. Geochim Cosmochim Acta 71:2569-2590

Mitchell PJ, Simpson AJ, Soong R, Simpson MJ (2016) Biochar amendment altered the molecular-level composition of native soil organic matter in a temperate forest soil. Environ Chem:in press

Mitchell PJ, Simpson AJ, Soong R, Simpson MJ (2015) Shifts in microbial community and waterextractable organic matter composition with biochar amendment in a temperate forest soil. Soil Biol Biochem 81:244-254

Moore JD, Ouimet R (2014) Effects of two types of Ca fertilizer on sugar maple nutrition, vigor and growth after 7 years. For Ecol Manage 320:1-5 
Moore JD, Ouimet R, Long RP, Bukaveckas PA (2015) Ecological benefits and risks arising from liming sugar maple dominated forests in northeastern North America. Environ Rev 23:66-77

Mukherjee A, Zimmerman AR (2013) Organic carbon and nutrient release from a range of laboratoryproduced biochars and biochar-soil mixtures. Geoderma 193:122-130

Nelissen V, Rütting T, Huygens D, Staelens J, Ruysschaert G, Boeckx P (2012) Maize biochars accelerate short-term soil nitrogen dynamics in a loamy sand soil. Soil Biol Biochem 55:20-27

Noyce GL, Basiliko N, Fulthorpe R, Sackett TE, Thomas SC (2015) Soil microbial responses over 2 years following biochar addition to a north temperate forest. Biol Fertil Soils 51:649-659

Olsen SR, Cole CV, Watanabe FS, Dean LA (1954) Estimation of available phosphorus in soils by extraction with sodium bicarbonate. USDA Circular 939:1-19

Orth AB, Royse DJ, Tien M (1993) Ubiquity of lignin-degrading peroxidases among various wooddegrading fungi. Appl Environ Microbiol 59:4017-4023

Otto A, Simpson MJ (2005) Degradation and preservation of vascular plant-derived biomarkers in grassland and forest soils from Western Canada. Biogeochemistry 74:377-409

Otto A, Simpson MJ (2006a) Evaluation of $\mathrm{CuO}$ oxidation parameters for determining the source and stage of lignin degradation in soil. Biogeochemistry 80:121-142

Otto A, Simpson MJ (2006b) Sources and composition of hydrolysable aliphatic lipids and phenols in soils from western Canada. Org Geochem 37:385-407

Peng Y, Thomas SC (2010) Influence of non-nitrogenous soil amendments on soil $\mathrm{CO}_{2}$ efflux and fine root production in an N-saturated northern hardwood forest. Ecosystems 13:1145-1156

Prayogo C, Jones JE, Baeyens J, Bending GD (2014) Impact of biochar on mineralisation of C and N from soil and willow litter and its relationship with microbial community biomass and structure. Biol Fertil Soils 50:695-702

Sackett TE, Basiliko N, Noyce GL, Winsborough C, Schurman J, Ikeda C, Thomas SC (2015) Soil and greenhouse gas responses to biochar additions in a temperate hardwood forest. GCB Bioenergy 7:1062-1074

Santos F, Torn MS, Bird JA (2012) Biological degradation of pyrogenic organic matter in temperate forest soils. Soil Biol Biochem 51:115-124

Sheibani S, Yanni SF, Wilhelm R, Whalen JK, Whyte LG, Greer CW, Madramootoo CA (2013) Soil bacteria and archaea found in long-term corn (Zea mays L.) agroecosystems in Quebec, Canada. Can J Soil Sci 93:45-57

Simpson AJ, Song G, Smith E, Lam B, Novotny EH, Hayes MHB (2007) Unraveling the structural components of soil humin by use of solution-state nuclear magnetic resonance spectroscopy. Environ Sci Technol 41:876-883

Simpson AJ, McNally DJ, Simpson MJ (2011) NMR spectroscopy in environmental research: from molecular interactions to global processes. Prog Nucl Magn Reson Spectrosc 58:97-175

Singh N, Abiven S, Maestrini B, Bird JA, Torn MS, Schmidt MWI (2014) Transformation and stabilization of pyrogenic organic matter in a temperate forest field experiment. Global Change Biol 20:1629-1642

Sitaula BK, Bakken LR, Abrahamsen G (1995) N-fertilization and soil acidification effects on $\mathrm{N}_{2} \mathrm{O}$ and $\mathrm{CO}_{2}$ emission from temperate pine forest soil. Soil Biol Biochem

Sjöström E (1993) Wood Chemistry, Fundamentals and Applications, 2nd ed. Academic Press, London, UK

Smebye A, Alling V, Vogt RD, Gadmar TC, Mulder J, Cornelissen G, Hale SE (2016) Biochar amendment to soil changes dissolved organic matter content and composition. Chemosphere 142:100-105

Smith JL, Collins HP, Bailey VL (2010) The effect of young biochar on soil respiration. Soil Biol Biochem 42:2345-2347 
Soil Classification Working Group (1998) The Canadian System of Soil Classification. NRC Research Press, Ottawa, ON, Canada

Spokas KA, Novak JM, Stewart CE, Cantrell KB, Uchimiya M, DuSaire MG, Ro KS (2011) Qualitative analysis of volatile organic compounds on biochar. Chemosphere 85:869-882

Steinbeiss S, Gleixner G, Antonietti M (2009) Effect of biochar amendment on soil carbon balance and soil microbial activity. Soil Biol Biochem 41:1301-1310

Sullivan BW, Alvarez-Clare S, Castle SC, Porder S, Reed SC, Schreeg L, Townsend AR, Cleveland CC (2014) Assessing nutrient limitation in complex forested ecosystems: Alternatives to large-scale fertilization experiments. Ecology 95:668-681

Thies JE, Rillig MC (2009) Characteristics of biochar: Biological properties. In: Lehmann J, Joseph S (eds) Biochar for Environmental Management: Science and Technology. Earthscan, London, UK, pp 85-105

Thomas SC, Gale N (2015) Biochar and forest restoration: a review and meta-analysis of tree growth responses. New For 46:931-946

Tuomela M, Vikman M, Hatakka A, Itävaara M (2000) Biodegradation of lignin in a compost environment: A review. Bioresour Technol 72:169-183

Uchimiya M, Lima IM, Klasson KT, Wartelle LH (2010) Contaminant immobilization and nutrient release by biochar soil amendment: Roles of natural organic matter. Chemosphere 80:935-940

van der Heijden MGA, Bardgett RD, van Straalen NM (2008) The unseen majority: Soil microbes as drivers of plant diversity and productivity in terrestrial ecosystems. Ecol Lett 11:296-310

Vet R, Ro C (2008) Contribution of Canada-United States transboundary transport to wet deposition of sulphur and nitrogen oxides - A mass balance approach. Atmos Environ 42:2518-2529

von Lützow M, Kögel-Knabner I, Ekschmitt K, Matzner E, Guggenberger G, Marschner B, Flessa H (2006) Stabilization of organic matter in temperate soils: Mechanisms and their relevance under different soil conditions - A review. Eur J Soil Sci 57:426-445

Watzinger A, Feichtmair S, Kitzler B, Zehetner F, Kloss S, Wimmer B, Zechmeister-Boltenstern S, Soja G (2014) Soil microbial communities responded to biochar application in temperate soils and slowly metabolized ${ }^{13} \mathrm{C}$-labelled biochar as revealed by ${ }^{13} \mathrm{C}$ PLFA analyses: Results from a shortterm incubation and pot experiment. Eur J Soil Sci 65:40-51

West TO, McBride AC (2005) The contribution of agricultural lime to carbon dioxide emissions in the United States: Dissolution, transport, and net emissions. Agric Ecosyst Environ 108:145-154

Zelles L (1999) Fatty acid patterns of phospholipids and lipopolysaccharides in the characterisation of microbial communities in soil: A review. Biol Fertil Soils 29:111-129

Zhu F, Lu X, Liu L, Mo J (2015) Phosphate addition enhanced soil inorganic nutrients to a large extent in three tropical forests. Sci Rep 5:7923

Zimmerman AR, Gao B, Ahn MY (2011) Positive and negative carbon mineralization priming effects among a variety of biochar-amended soils. Soil Biol Biochem 43:1169-1179 
Table 1. Summary of microbial community and soil organic matter (OM) components that were characterized in the amended surface mineral soils (0-5 cm depth) using biomarker and NMR techniques, along with the results observed and their biogeochemical interpretation.

Measured soil biomarker

- Bacterial PLFAs (Gram-positive, Gram-negative, actinomycetes)

- Fungal PLFA

- Soil fungal activity

- Ratio of Gram-negative/Grampositive PLFAs

- Ratio of bacterial/fungal PLFAs

- Short-chain aliphatic lipids

- Long-chain aliphatic lipids bacteria in soil

\section{Solvent extraction}

- Sugars

- Ergosterol soil OM inputs

- Soil fungal activity inputs

\section{Information obtained}

Results

- Soil bacterial activity

- Increased concentrations with biochar, $\mathrm{P}$ and biochar + $\mathrm{P}$

- Increased concentrations with biochar and biochar $+\mathrm{P}$

- Concentration did not change with $\mathrm{P}$ fertilization

- Relative proportion of Gramnegative and Gram-positive

- Relative proportion of bacteria and fungi in soil

- Plant- and microbial-derived

- Microbial-derived soil OM

- Plant-derived soil OM inputs
- Ratio decreased with biochar, $\mathrm{P}$ and biochar $+\mathrm{P}$

- Ratio decreased with biochar and biochar $+\mathrm{P}$

- Ratio did not change with P fertilization

- Increased concentrations with biochar, $\mathrm{P}$ and biochar + $\mathrm{P}$

- Increased concentrations with biochar and biochar $+\mathrm{P}$

- Concentration did not change with $\mathrm{P}$ fertilization

- Increased concentrations with biochar and biochar $+\mathrm{P}$ Concentration did not change with $\mathrm{P}$ fertilization

- Increased concentrations with biochar, $\mathrm{P}$ and biochar + $\mathrm{P}$
Biogeochemical interpretation

- Bacterial activity was stimulated

- Fungal activity was stimulated

- No changes in fungal activity

- Bacterial community shifted toward Gram-positive bacteria

- Microbial community shifted toward fungi

- Microbial community composition did not shift

- Higher inputs of plant- and microbial-derived $\mathrm{OM}$

- Fungal activity was stimulated

- No changes in fungal activity

- Higher inputs of microbialderived OM

- No changes in microbialderived soil OM inputs

- Higher inputs of plantderived OM 
- Steroids and triterpenoids

- Ratio of acyclic/cyclic lipids

- Ratio of sterols/sterones

Base hydrolysis

- Total cutin monomers

- Total suberin monomers

- Ratio of suberin/cutin

- Ratios of $\omega-\mathrm{C}_{16} / \Sigma \mathrm{C}_{16}$ and $\omega$ $\mathrm{C}_{18} / \Sigma \mathrm{C}_{18}$ acids

- Ratio of $\Sigma$ mid-chain acids/total suberin and cutin components

\section{CuO oxidation}

- Total lignin monomers and total lignin dimers

- Ratio of lignin monomers/dimers
- Plant-derived soil OM inputs

- Relative proportion of acyclic and cyclic lipids in soil

- Indicator of sterol degradation

- Cutin-derived soil OM inputs

- Suberin-derived soil OM inputs

- Relative proportion of suberin and cutin in soil

- Indicators of cutin degradation

- Indicator of suberin and cutin degradation

- Extractable monomeric and dimeric sidechains of lignin

- Relative proportion of extractable monomeric and dimeric lignin sidechains
- Increased concentrations with biochar, $\mathrm{P}$ and biochar + $P$

- Ratio increased with biochar, $\mathrm{P}$ and biochar $+\mathrm{P}$

- Ratio did not change with biochar, $\mathrm{P}$ or biochar $+\mathrm{P}$

- Increased concentrations with biochar, $\mathrm{P}$ and biochar + $\mathrm{P}$

- Increased concentrations with biochar, $\mathrm{P}$ and biochar + $\mathrm{P}$

- Ratio decreased with biochar, $\mathrm{P}$ and biochar $+\mathrm{P}$

- Ratio did not change with biochar, $\mathrm{P}$ or biochar $+\mathrm{P}$

- Ratio did not change with biochar, $\mathrm{P}$ or biochar $+\mathrm{P}$

- Increased concentrations with biochar and biochar $+\mathrm{P}$

- Concentration did not change with $\mathrm{P}$ fertilization

- Ratio increased with biochar and biochar $+\mathrm{P}$

- Ratio did not change with P fertilization
- Higher inputs of plantderived OM

- OM compositional shift toward a higher proportion of cyclic lipids

- No change in sterol degradation

- Higher inputs of cutinderived OM components

- Higher inputs of suberinderived OM components

- OM compositional shift toward more cutin components

- No change in cutin degradation

- No change in suberin and cutin degradation

- Higher concentrations of extractable lignin components No changes in extractable lignin

- Macromolecular lignin contained a greater proportion of monomeric sidechains

- No changes in the proportion of monomers and dimers 
- Acid-to-aldehyde ratios (syringyl and vanillyl monomers)

\section{Solution-state H NMR spectroscopy}

- Base-extractable soil OM
- Indicator of lignin sidechain oxidation

- Relative proportion of specific organic $\mathrm{C}$ functional groups in soil OM
- Ratios did not change with biochar, $\mathrm{P}$ or biochar $+\mathrm{P}$

- Decreased proportion of carbohydrates, increased proportion of alkyl-derived $\mathrm{OM}$ with biochar, $\mathrm{P}$ and biochar $+\mathrm{P}$
- Enhanced degradation of labile OM, accumulation of more recalcitrant alkyl OM components 


\section{Figure captions}

Fig. 1 Principal component analysis (PCA) scores plots of (a) phospholipid fatty acid and (b) total soil organic matter biomarker concentrations in the biochar, $\mathrm{P}$ and biochar $+\mathrm{P}$-amended soils at the $0-5 \mathrm{~cm}$ and 5-15 cm depths. The percentage of variance explained by each component is indicated in brackets on each axis. The values shown are mean scores with standard error $(n=3)$. Treatment data labels indicate the biochar application rate and the presence or absence of $\mathrm{P}$ fertilization

Fig. 2 Total concentrations of (a) Gram-negative, (b) Gram-positive, (c) actinomycete and (d) fungal phospholipid fatty acids (PLFAs) as well as the ratios of (e) Gram-negative/Gram-positive PLFAs and (f) bacterial/fungal PLFAs in the $0-5 \mathrm{~cm}$ mineral soil during a three-year biochar and $\mathrm{P}$ amendment study. Treatment data labels indicate the biochar application rate and the presence or absence of $\mathrm{P}$ fertilization. Asterisks indicate values that are statistically significant $(p \leq 0.05)$ from the unamended soil

Fig. 3 Total concentrations of solvent-extractable (a) sugars, (b) short-chain $n$-alkanoic acids, (c) longchain $n$-alkanes, (d) long-chain $n$-alkanols, (e) long-chain $n$-alkanoic acids, (f) steroids, (g) triterpenoids and (h) ergosterol as well as (i) the ratio of acyclic/cyclic aliphatic lipids in the $0-5 \mathrm{~cm}$ mineral soil during a three-year biochar and $\mathrm{P}$ amendment study. Treatment data labels indicate the biochar application rate and the presence or absence of $\mathrm{P}$ fertilization. Asterisks indicate values that are statistically significant $(p \leq 0.05)$ from the unamended soil

Fig. 4 Total concentrations and ratios of biomarkers isolated using chemolytic extraction techniques, including base-hydrolyzable (a) cutin and (b) suberin compounds, (c) the ratio of suberin/cutin biomarkers, as well as $\mathrm{CuO}$ oxidation products including lignin-derived phenol (d) monomers, (e) 
dimers and (f) the ratio of monomers/dimers in the $0-5 \mathrm{~cm}$ mineral soil during a three-year biochar and $\mathrm{P}$ amendment study. Treatment data labels indicate the biochar application rate and the presence or absence of $\mathrm{P}$ fertilization. Asterisks indicate values that are statistically significant $(p \leq 0.05)$ from the unamended soil

Fig. 5 Representative solution-state (a) 1-D ${ }^{1} \mathrm{H}$, (b) 1-D diffusion-edited ${ }^{1} \mathrm{H}$ and (c) $2-\mathrm{D}{ }^{1} \mathrm{H}-{ }^{13} \mathrm{C}$ heteronuclear single quantum coherence (HSQC) nuclear magnetic resonance (NMR) spectra of baseextractable soil OM in the amended soil samples. Braces indicate integrated regions of the 1-D spectra for protons in the following specific chemical environments: (1) aliphatic (0.6-1.3 ppm); (2) $N$ - and $O$ substituted aliphatic (1.3-2.9 ppm); (3) $O$-alkyl (2.9-4.1 ppm); (4) $\alpha$-proton of peptides (4.1-4.8 ppm); (5) anomeric protons of carbohydrates (4.8-5.2 ppm); (6) aromatic and phenolic (6.2-7.8 ppm); and (7) amide (7.8-8.4 ppm). The asterisk $(*)$ denotes the NMR solvent (DMSO- $\left.d_{6}\right)$. The arrows and dashed boxes outline regions of the 2-D ${ }^{1} \mathrm{H}_{-}{ }^{13} \mathrm{C}$ HSQC NMR spectrum that were used to calculate normalized area ratios (defined in Table S19 of the Supplementary Material) 
Fig. 1
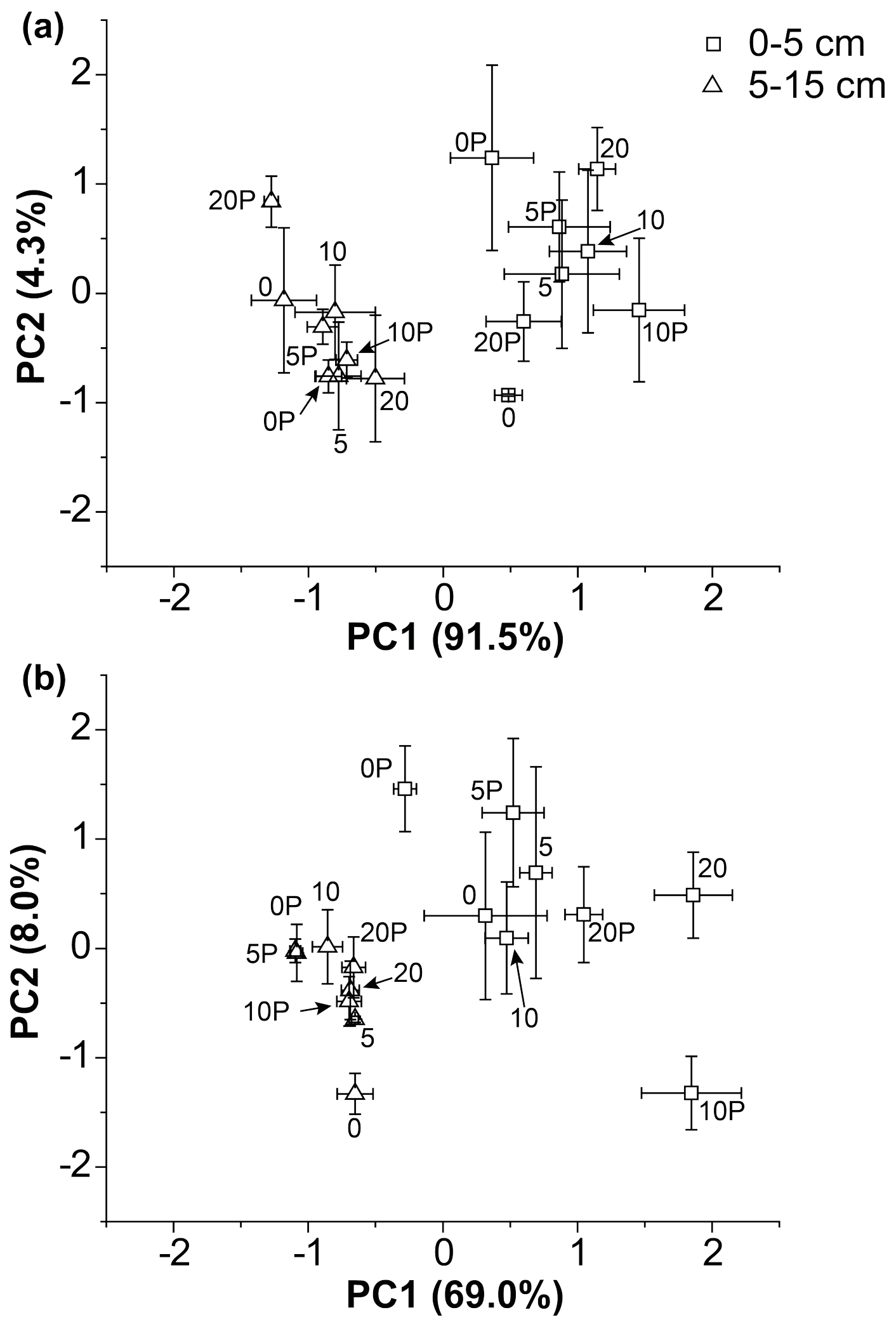
Fig. 2
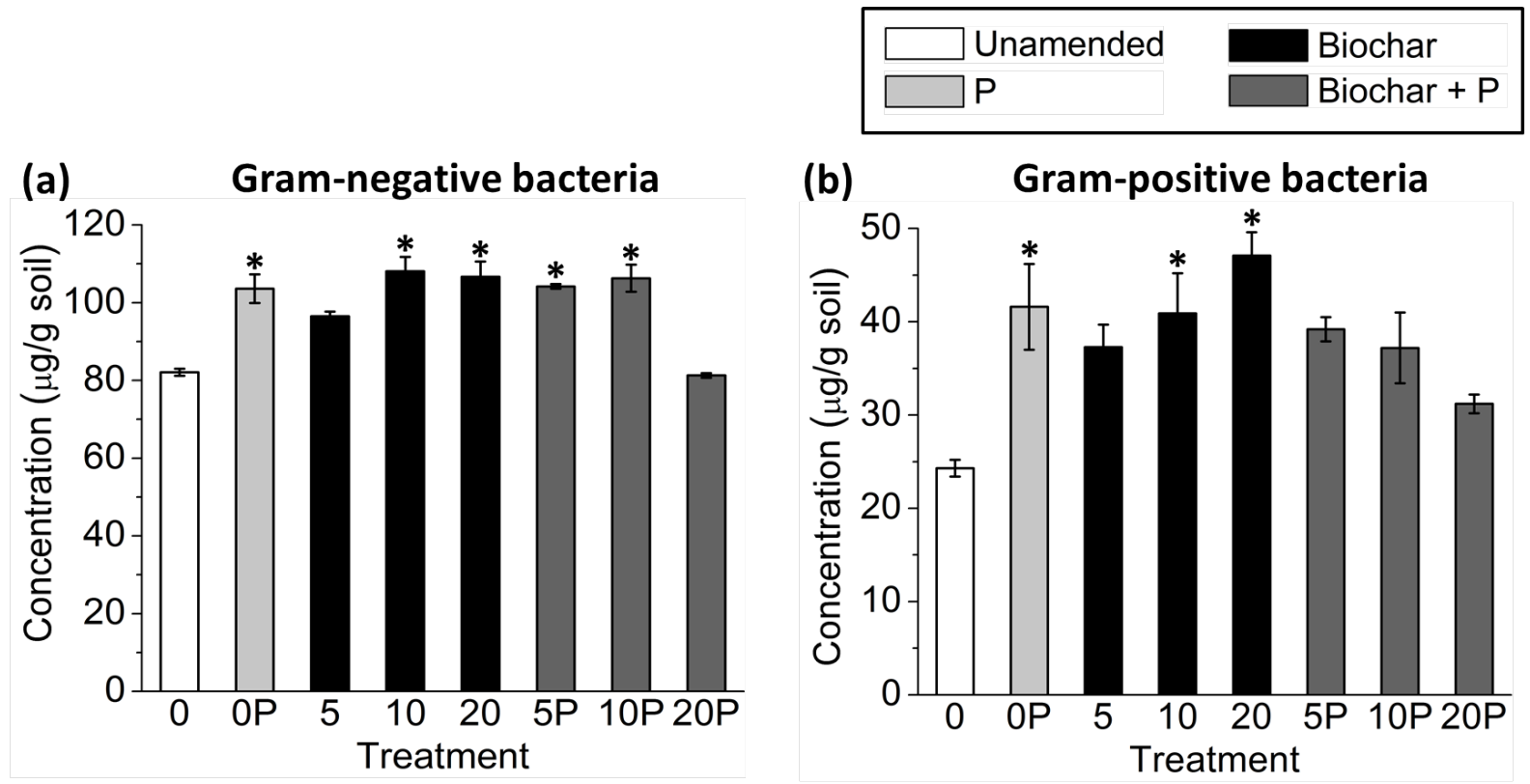

(c) Actinomycetes

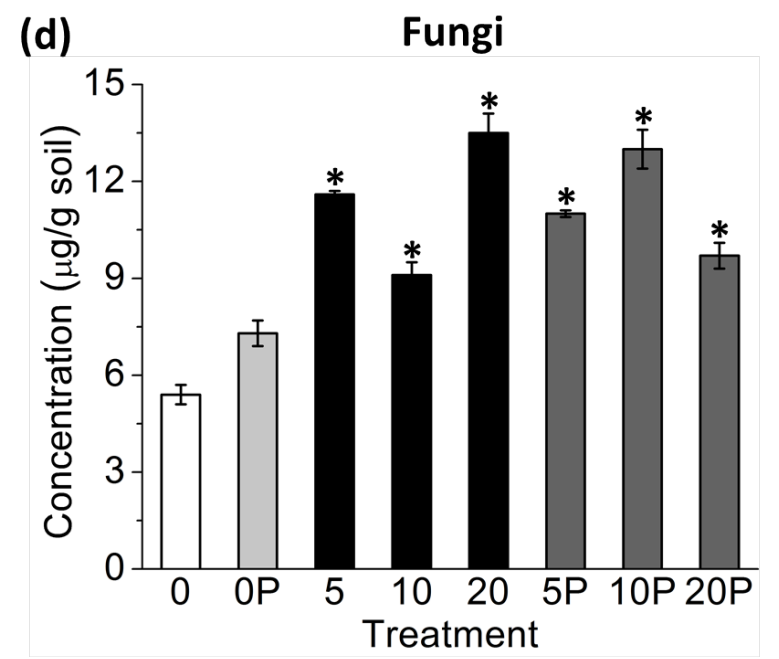

(e) Gram-negative/Gram-positive bacteria
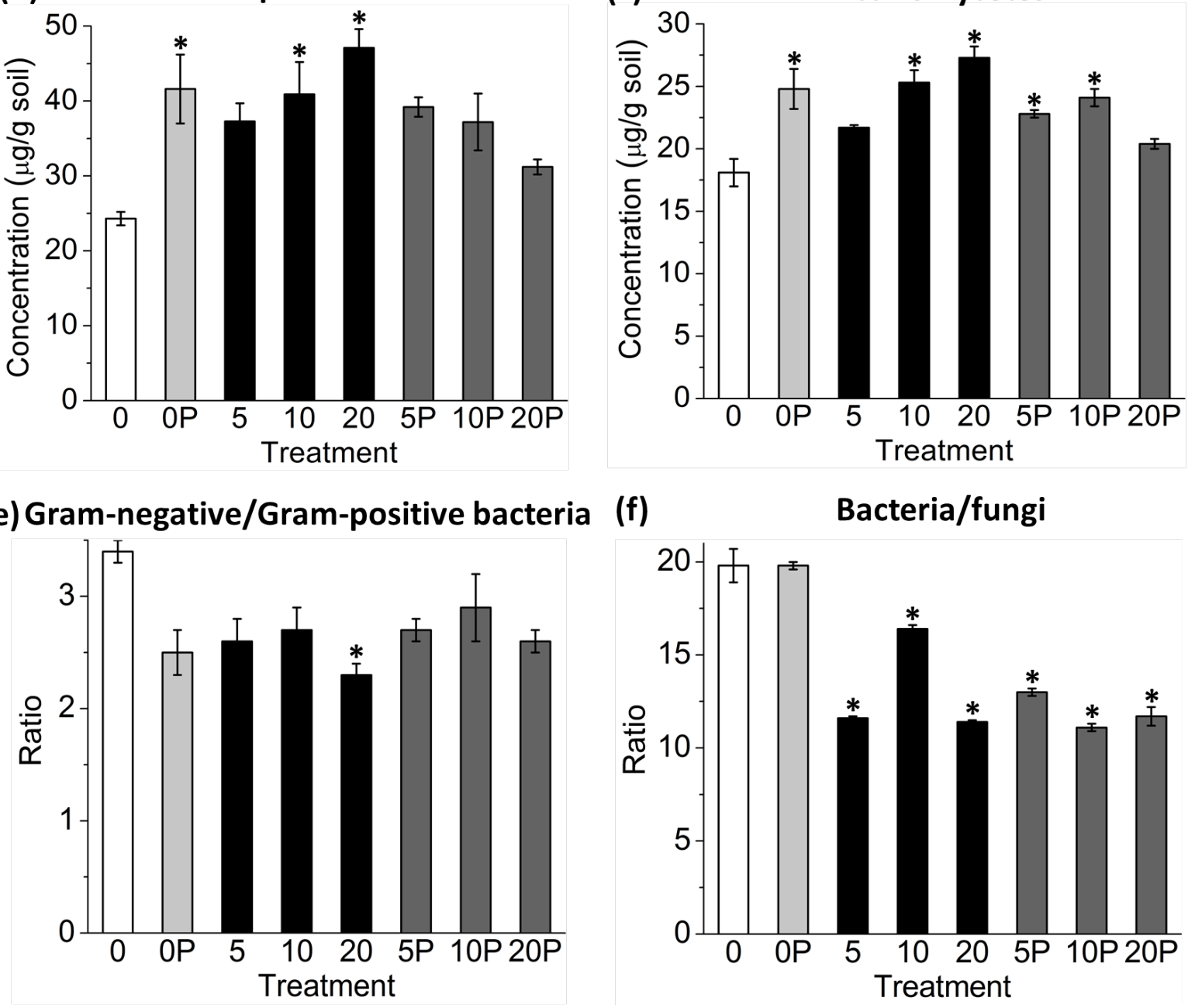

Bacteria/fungi

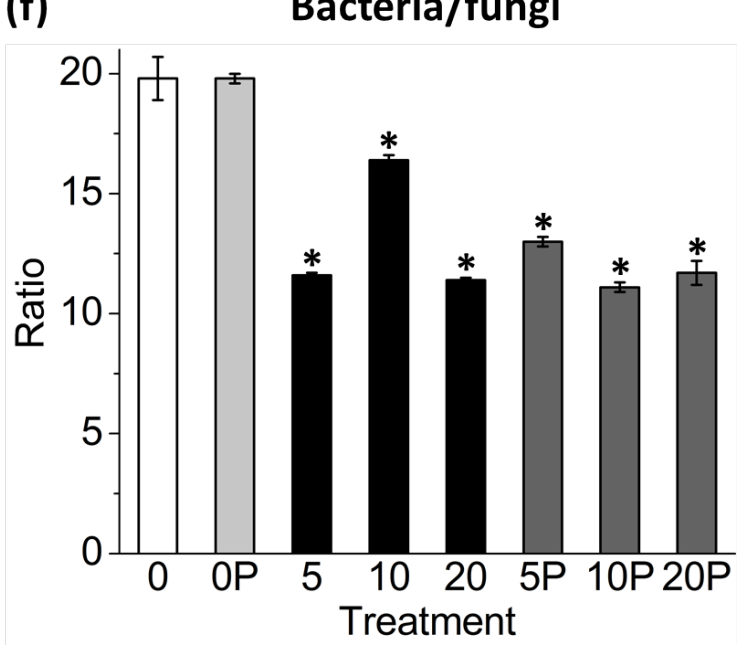


Fig. 3
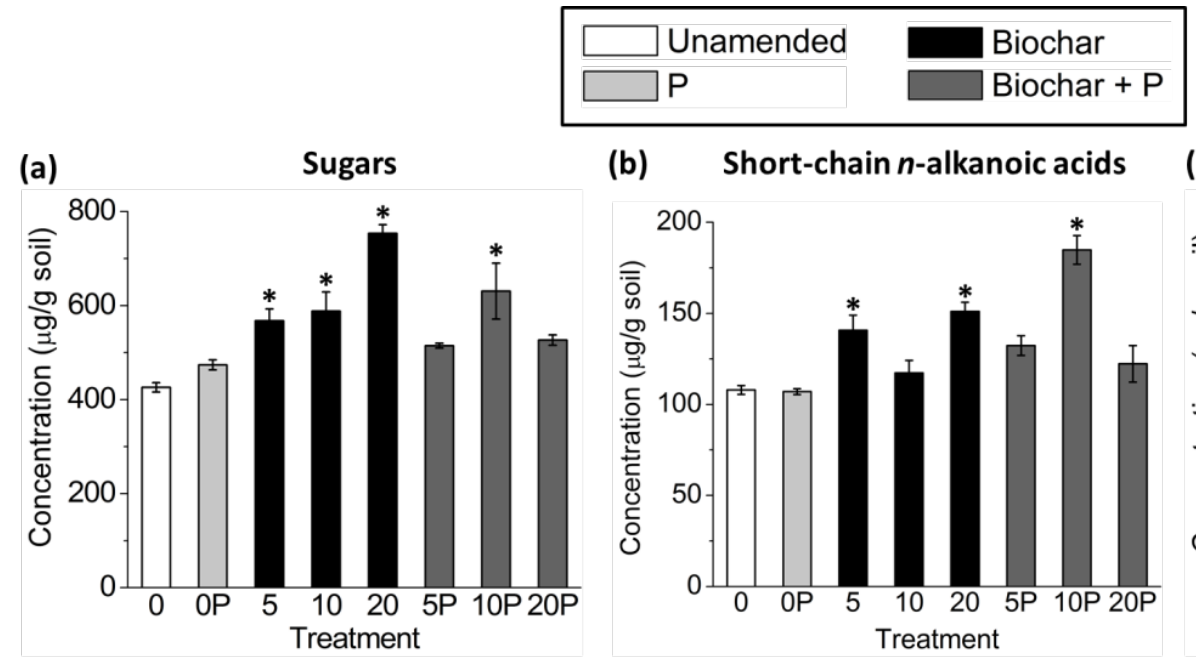

(b) Short-chain $\boldsymbol{n}$-alkanoic acids

(c) Long-chain $n$-alkanes
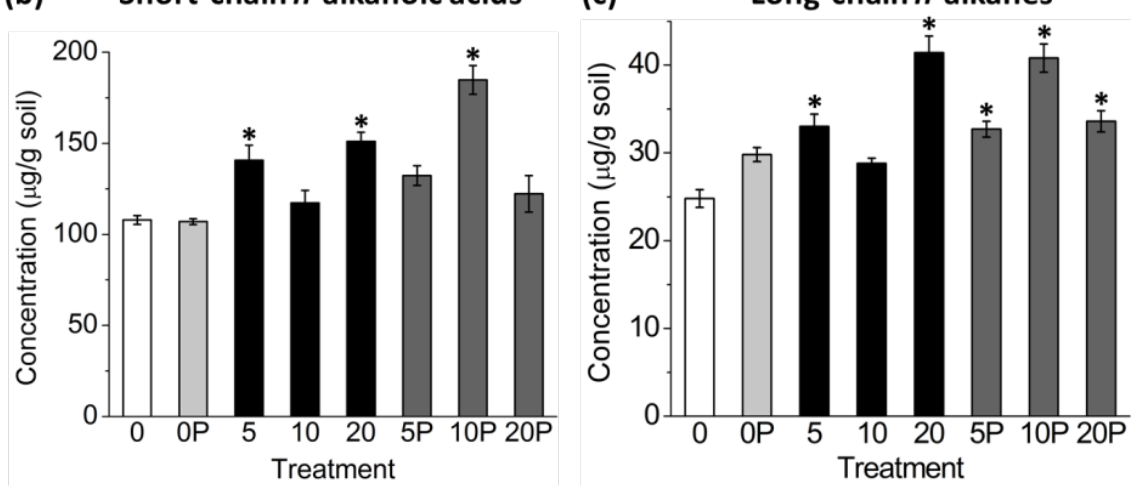

(d)

Long-chain $n$-alkanols

(e)

Long-chain $\boldsymbol{n}$-alkanoic acids

(f)

Steroids
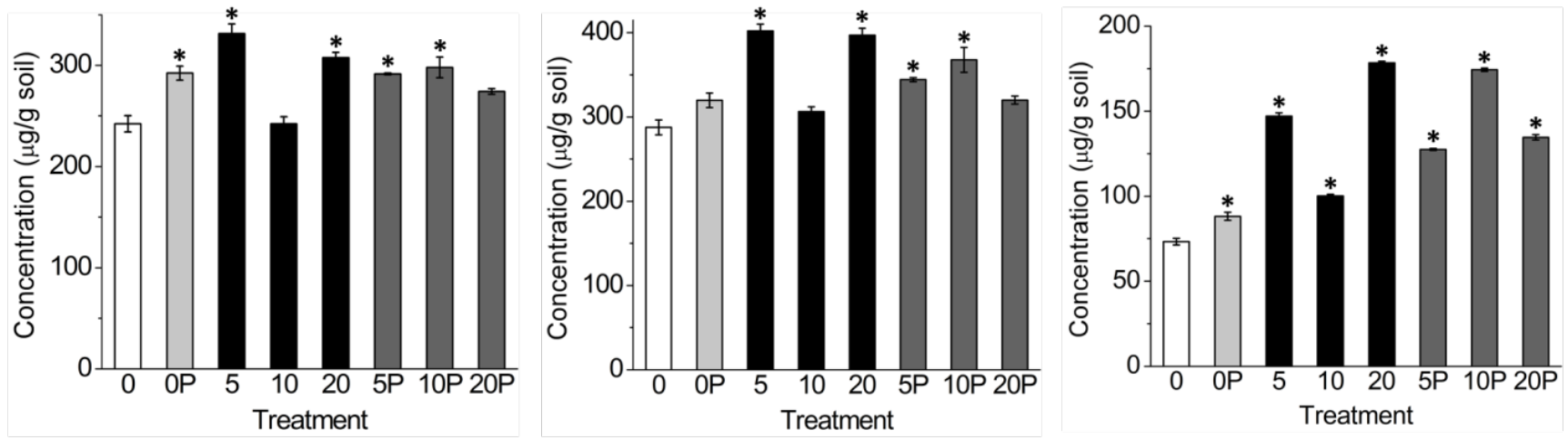

(g)

Triterpenoids

(h) Ergosterol

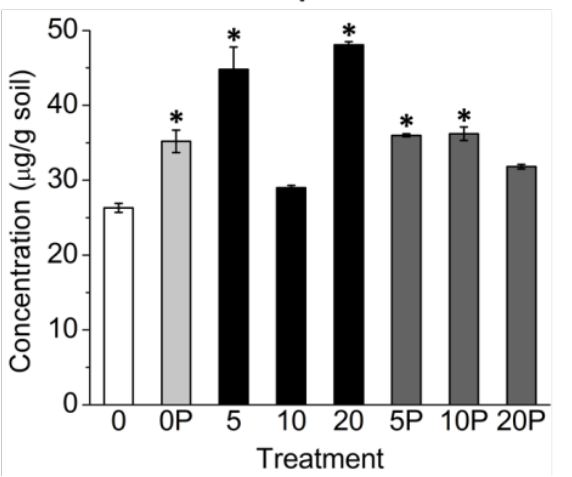

(i)

Acyclic/cyclic lipids
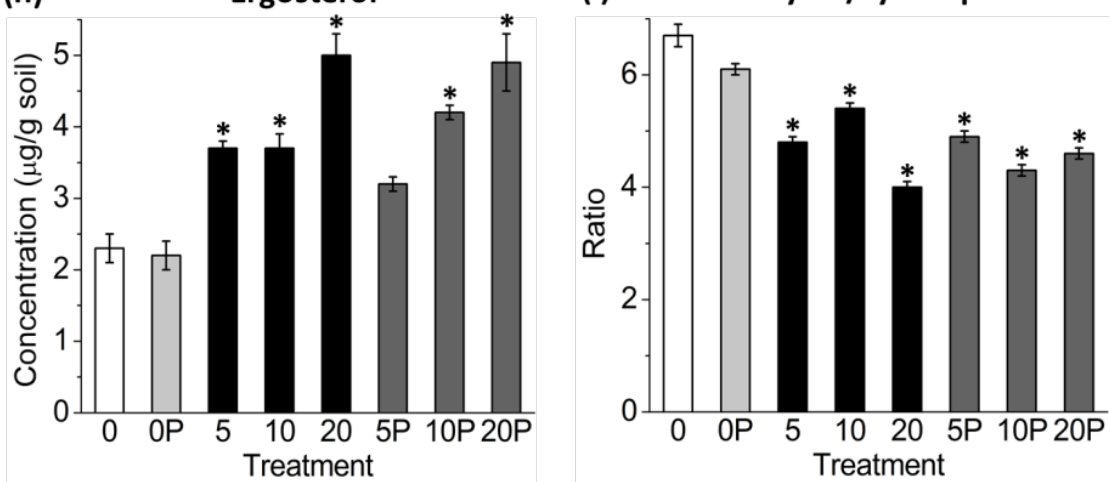
Fig. 4

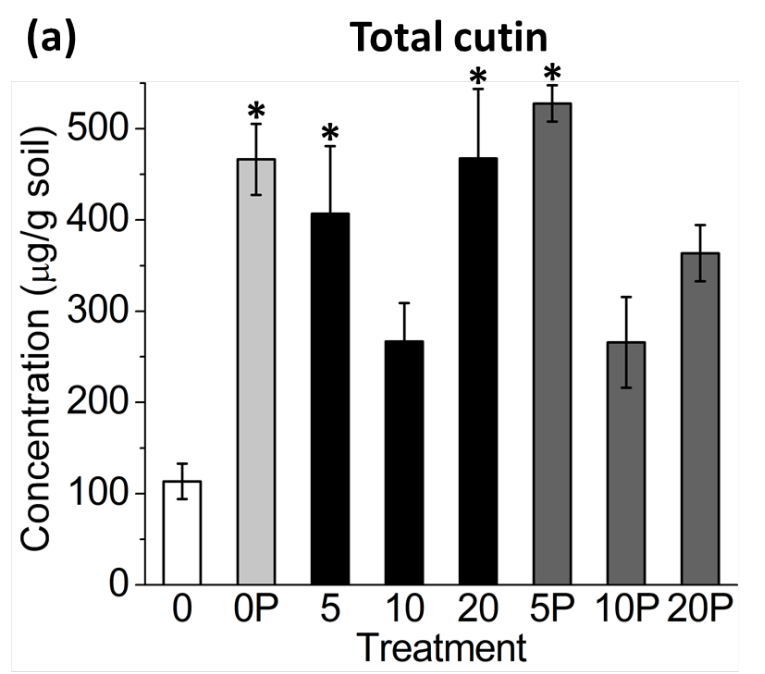

(b)

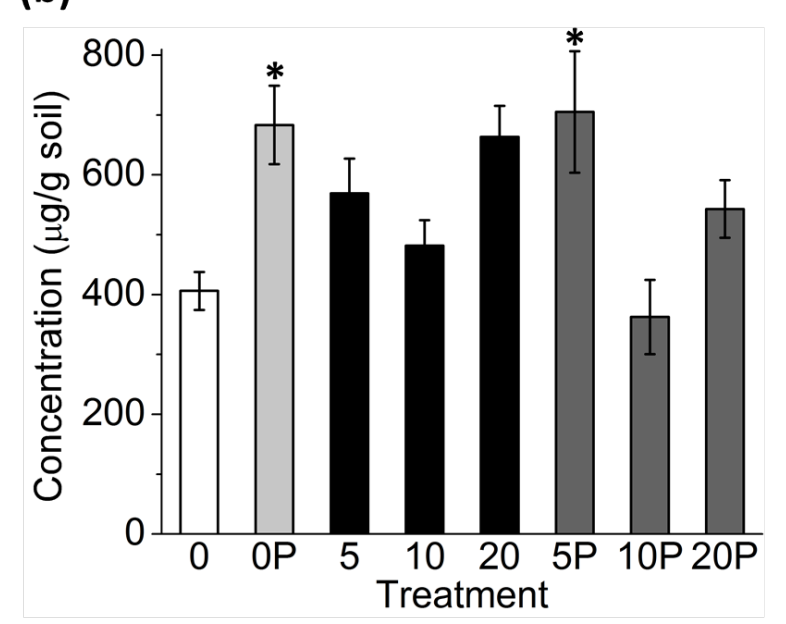

(d)

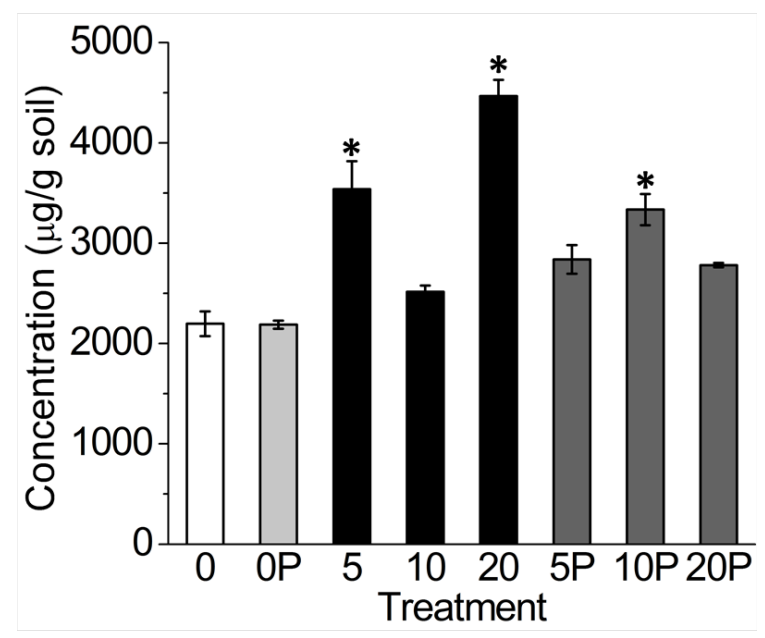

(e)

Total lignin dimers

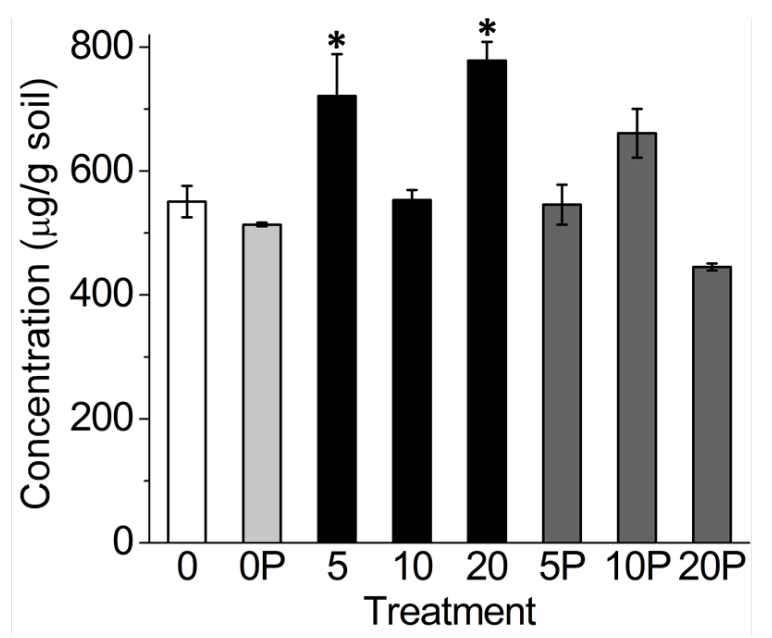

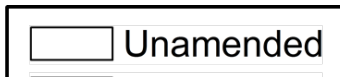

$P$

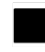

$\square$

Biochar Biochar + P

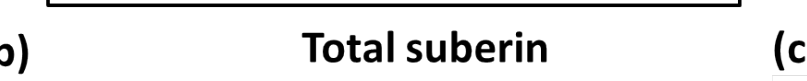

(c)

Suberin/cutin

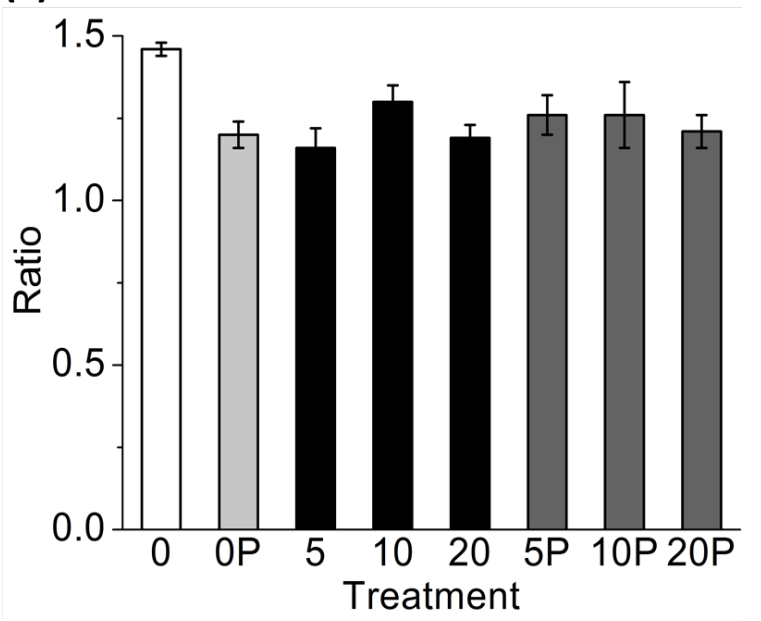

(f)

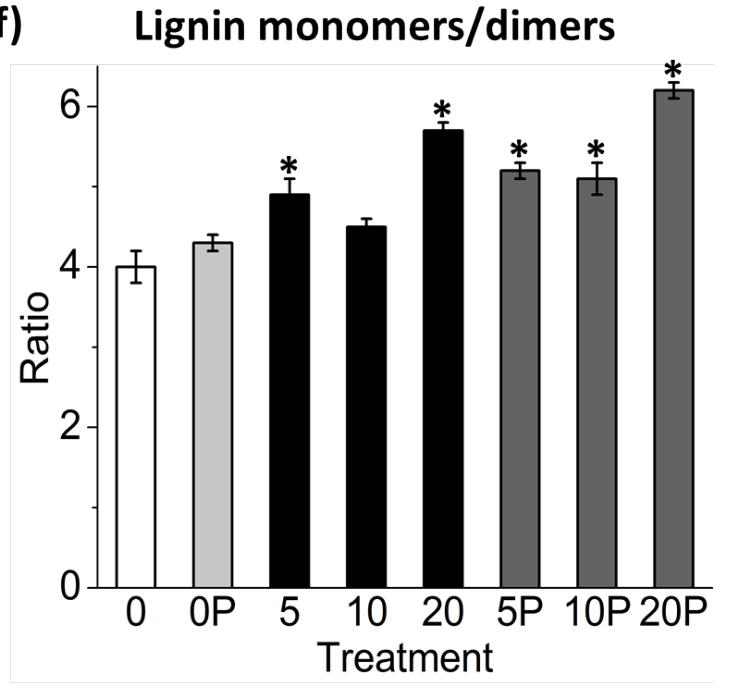


Fig. 5

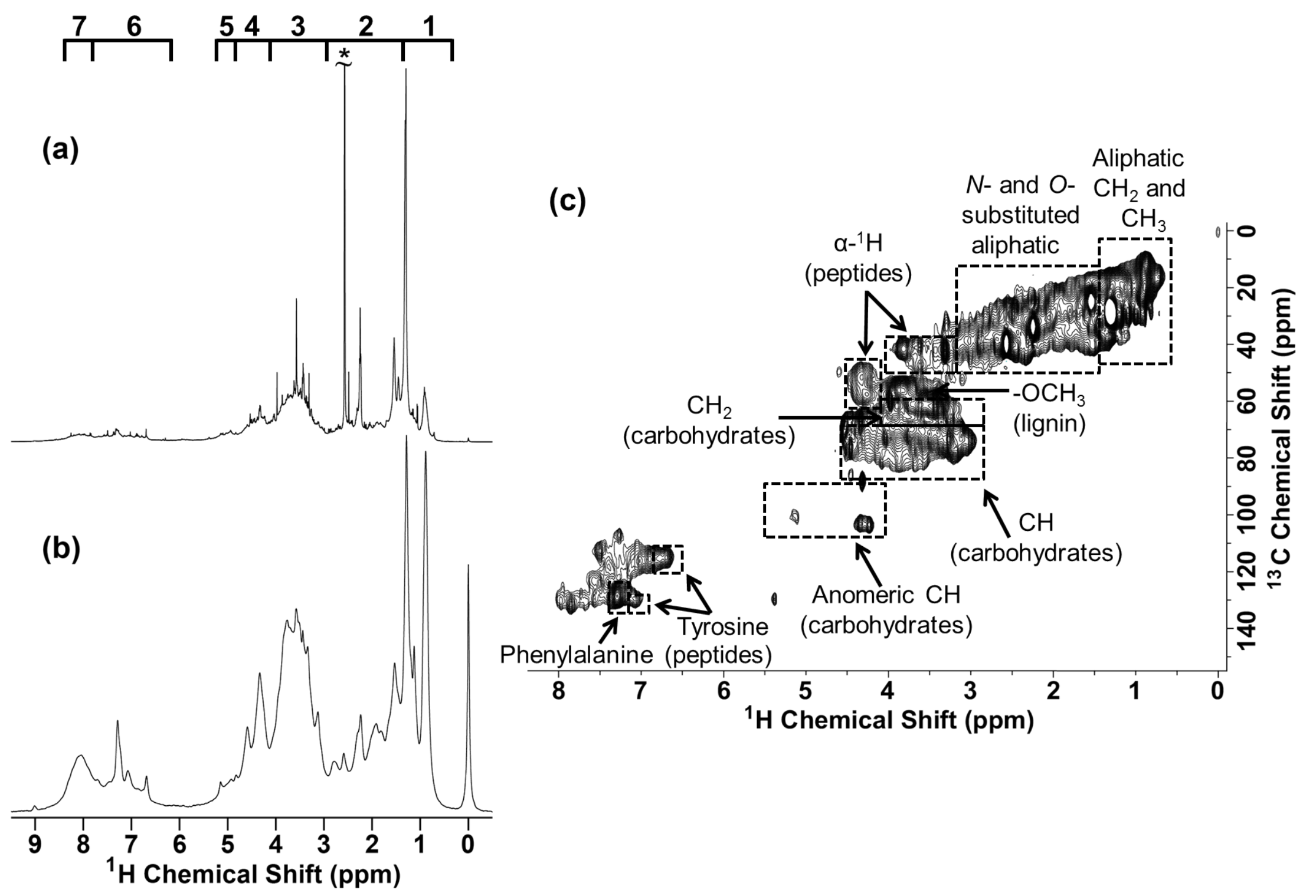

